\title{
Topoisomerase Inhibitors: Fluoroquinolone Mechanisms of Action and Resistance
}

\author{
David C. Hooper ${ }^{1}$ and George A. Jacoby ${ }^{2}$ \\ ${ }^{1}$ Division of Infectious Diseases, Massachusetts General Hospital, Boston, Massachusetts 02114 \\ ${ }^{2}$ Lahey Hospital and Medical Center, Burlington, Massachusetts 01805 \\ Correspondence: dhooper@partners.org
}

\begin{abstract}
Quinolone antimicrobials are widely used in clinical medicine and are the only current class of agents that directly inhibit bacterial DNA synthesis. Quinolones dually target DNA gyrase and topoisomerase IV binding to specific domains and conformations so as to block DNA strand passage catalysis and stabilize DNA-enzyme complexes that block the DNA replication apparatus and generate double breaks in DNA that underlie their bactericidal activity. Resistance has emerged with clinical use of these agents and is common in some bacterial pathogens. Mechanisms of resistance include mutational alterations in drug target affinity and efflux pump expression and acquisition of resistance-conferring genes. Resistance mutations in one or both of the two drug target enzymes are commonly in a localized domain of the GyrA and ParC subunits of gyrase and topoisomerase IV, respectively, and reduce drug binding to the enzyme-DNA complex. Other resistance mutations occur in regulatory genes that control the expression of native efflux pumps localized in the bacterial membrane(s). These pumps have broad substrate profiles that include other antimicrobials as well as quinolones. Mutations of both types can accumulate with selection pressure and produce highly resistant strains. Resistance genes acquired on plasmids confer low-level resistance that promotes the selection of mutational high-level resistance. Plasmid-encoded resistance is because of Qnr proteins that protect the target enzymes from quinolone action, a mutant aminoglycoside-modifying enzyme that also modifies certain quinolones, and mobile efflux pumps. Plasmids with these mechanisms often encode additional antimicrobial resistances and can transfer multidrug resistance that includes quinolones.
\end{abstract}

$\mathrm{Q}$ uinolones have been used extensively for a wide range of clinical applications (Owens and Ambrose 2000; Kim and Hooper 2014). Nalidixic acid, a related naphthyridone structure and the first member of the class used clinically, was discovered by George Lesher as a byproduct of chloroquine synthesis in 1962 . Its use was limited to treatment of urinary tract infections and resistance emerged quickly
(Lesher et al. 1962). Medicinal chemists from a number of companies, however, subsequently modified the core quinolone and related chemical scaffolds, generating compounds with greater potency, broader spectra of activity, improved pharmacokinetics, and lower frequency of development of resistance (Domagala and Hagen 2003). An important addition of a fluorine substituent at position 6 added to po-

Editors: Lynn L. Silver and Karen Bush

Additional Perspectives on Antibiotics and Antibiotic Resistance available at www.perspectivesinmedicine.org

Copyright (C) 2016 Cold Spring Harbor Laboratory Press; all rights reserved; doi: 10.1101/cshperspect.a025320

Cite this article as Cold Spring Harb Perspect Med 2016;6:a025320 
D.C. Hooper and G.A. Jacoby

tency and became the common feature of the fluoroquinolone class with the introductions of norfloxacin in 1986 and ciprofloxacin in 1987 that showed substantially greater potency against Gram-negative bacteria. Subsequently, other fluoroquinolones, such as levofloxacin, gatifloxacin, moxifloxacin, and gemifloxacin were developed with increased activity against Gram-positive bacteria. Because of their potency, spectrum of activity, oral bioavailability, and generally good safety profile, fluoroquinolones were used widely for a range of clinical indications worldwide. Although still clinically valuable, fluoroquinolone use has been compromised by the emergence of bacterial resistance because of mutation and acquisition of plasmid-encoded genes. In the sections that follow, we review the mechanisms of quinolone action and resistance, which are summarized in Table 1.

\section{QUINOLONE MECHANISM OF ACTION}

Quinolones target two essential bacterial type II topoisomerase enzymes, DNA gyrase and DNA topoisomerase IV (Hooper 1997). Both enzymes are heterotetramers with two subunits, gyrase being constituted as $\mathrm{GyrA}_{2} \mathrm{GyrB}_{2}$ and topoisomerase IV as $\operatorname{ParC}_{2} \mathrm{ParE}_{2}$. GyrA is homologous to ParC, and GyrB homologous to ParE (Wang 1996). In Staphylococcus aureus, topoisomerase IV subunits historically have also been referred to as GrlA and GrlB. Both enzymes act by catalyzing a DNA double-strand break, passing another DNA strand through the break, and resealing the break (Aldred et al. 2014). DNA strand passing occurs via domains that are localized in GyrA and ParC, whereas ATPase activity, which is required for enzyme catalysis, occurs via domains localized in GyrB and ParE.

Quinolones bind reversibly to the complexes of DNA with gyrase and topoisomerase IV at the interface between protein and DNA near the active site tyrosine (Tyr122 for GyrA, Tyr120 for ParC in Escherichia coli numbering), which is transiently covalently linked to DNA during DNA strand passage, with intercalation into the cleaved DNA (Laponogov et al. 2009,
2013; Bax et al. 2010; Wohlkonig et al. 2010). In GyrA, a noncatalytic $\mathrm{Mg}^{2+}$ ion coordinated with four water molecules appears as a bridge for hydrogen bonding between quinolone and Ser83 and Asp87 (Wohlkonig et al. 2010), the two most commonly mutated amino acids in quinolone-resistant mutants. Although quinolones can bind to mycobacterial gyrase in the absence of DNA (Kumar et al. 2014), in E. coli, the gyrase-DNA complex shows increases in the amount and specificity of quinolone binding relative to gyrase alone (Shen et al. 1989; Willmott and Maxwell 1993).

Quinolones inhibit enzyme function by blocking the resealing of the DNA doublestrand break, but, in addition, this process stabilizes a catalytic intermediate covalent complex of enzyme and DNA that serves as a barrier to movement of the DNA replication fork (Wentzell and Maxwell 2000) or transcription complexes (Willmott et al. 1994) and can be converted to permanent double-strand DNA breaks (Drlica et al. 2008), thereby functioning as topoisomerase poisons (Kreuzer and Cozzarelli 1979). Quinolone interactions with DNA gyrase appear to result in more rapid inhibition of DNA replication than quinolone interactions with topoisomerase IV (Khodursky et al. 1995; Fournier et al. 2000), possibly relating to the overall proximity to the DNA replication complex of enzyme-binding sites on chromosomal DNA, with gyrase positioned ahead of the complex and topoisomerase IV behind it (Khodursky and Cozzarelli 1998). Quinolones can differ in their potency for the two enzymes, with a general pattern among quinolones in clinical use that there is greater activity against DNA gyrase in Gram-negative bacteria and greater activity against topoisomerase IV in Gram-positive bacteria; but exceptions occur, and some quinolones have similar potency against both enzymes (Blanche et al. 1996; Pan and Fisher 1997; Strahilevitz and Hooper 2005).

DNA strand breaks trigger bacterial SOS DNA repair responses (Piddock et al. 1990; Drlica et al. 2008) and, to the extent that repair is incomplete, generate quinolone bactericidal activity (Hiasa et al. 1996; Drlica and Zhao 1997; Drlica et al. 2008, 2009). Inhibition of 
Fluoroquinolone Mechanisms of Action and Resistance
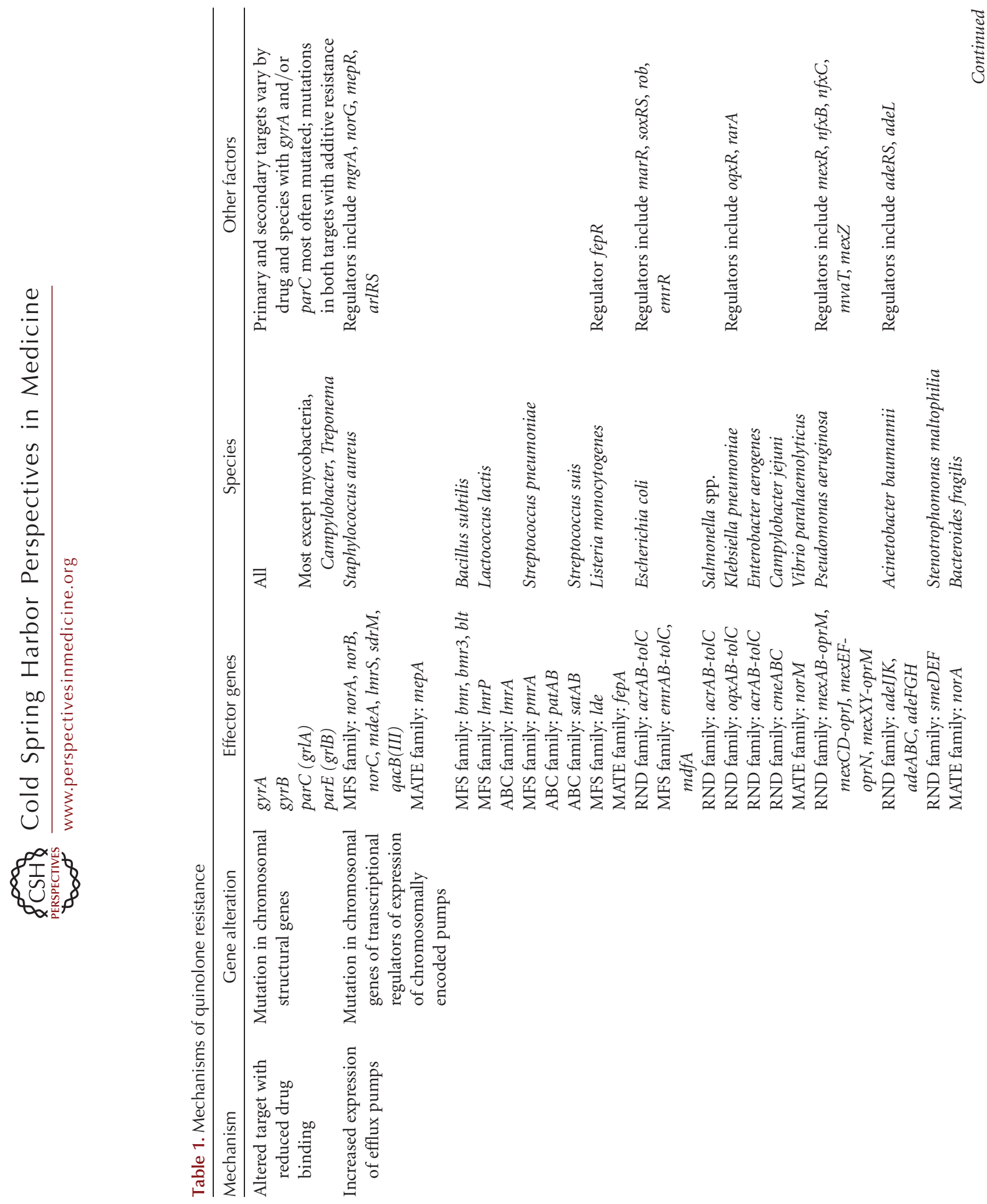
D.C. Hooper and G.A. Jacoby
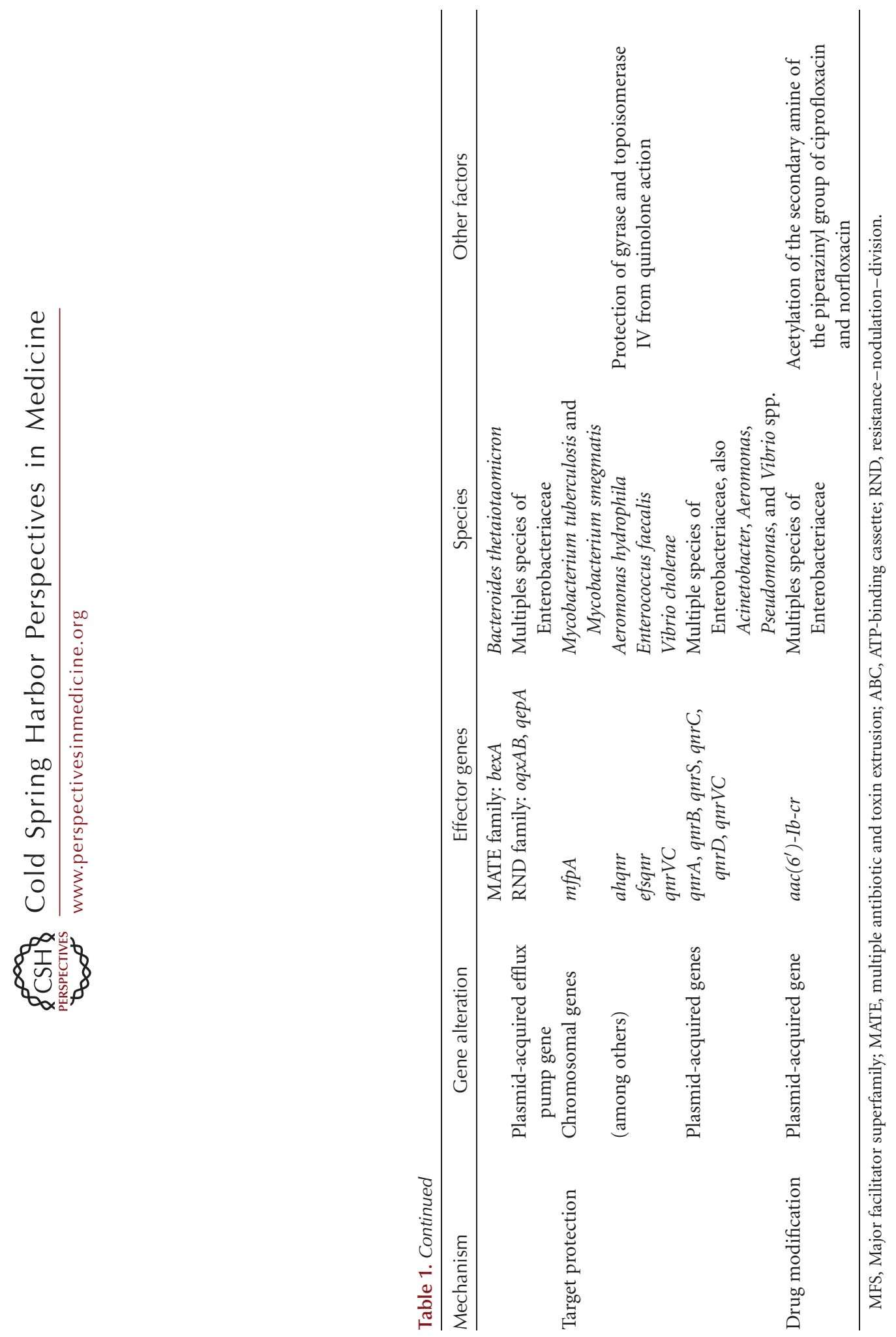
protein synthesis does not interfere with quinolone-mediated inhibition of DNA replication but can reduce bacterial killing, with variation in the magnitude of reduction seen with different quinolones (Lewin et al. 1991; Howard et al. 1993). These phenomena suggest that events in addition to DNA replication inhibition that may affect DNA or other cellular damage may also contribute to quinolone bactericidal activity, but the molecular mechanisms are not yet understood.

\section{QUINOLONE RESISTANCE BECAUSE OF MUTATIONAL ALTERATION IN TARGET ENZYMES}

Single amino acid changes in either gyrase or topoisomerase IV that confer quinolone resistance have been most commonly localized to the amino-terminal domains of GyrA (residues 67 to 106 for E. coli numbering) or ParC (residues 63 to 102). These domains are near the active site tyrosines (Tyr122 for GyrA, Tyr120 for ParC) of both enzymes (Morais Cabral et al. 1997; Laponogov et al. 2009, 2013; Wohlkonig et al. 2010). These domains have been termed the "quinolone resistance-determining region" (QRDR) of GyrA and ParC (Yoshida et al. 1990). The most common site of mutation in GyrA of E. coli is at Ser83 followed by Asp87, which as noted above are key residues in the binding of quinolones to GyrA or ParC. There is conservation of a Ser and another acidic residue separated by four amino acids in both GyrA and ParC in other species, and mutation in these residues can be frequently selected with quinolones in laboratory mutants and are frequently found in resistant clinical isolates (Hooper 2003; Drlica et al. 2009; Aldred et al. 2014). Ser83Trp and Ser83Leu mutations of E. coli GyrA have been associated with reduced binding of the quinolone norfloxacin and enoxacin to gyrase-DNA complexes (Willmott and Maxwell 1993; Yoshida et al. 1993; Willmott et al. 1994). A Ser81Phe resistance mutation in ParC of Bacillus anthracis appears also to show decreased quinolone binding to the enzymeDNA complex based on competition experiments with quinazolinediones, another gyr- ase-targeting class of compounds (Aldred et al. 2012). Mutations in the Ser and nearby acidic residues differ in their effects on catalytic efficiency of gyrase and topoisomerase IV, with mutation of the Ser residue generally having little effect and mutation in the acidic residue resulting in a five- to 10 -fold decrease in catalytic efficiency (Hiasa 2002; Aldred et al. 2014).

Resistance mutations in GyrB and ParE are substantially less common than those in GyrA and ParC in resistant clinical isolates. In E. coli, mutations at Asp426 and Lys447 of GyrB and Leu445 of ParE, as well as mutations at similar positions in other species, can cause resistance (Yoshida et al. 1991; Ito et al. 1994; Gensberg et al. 1995; Breines et al. 1997; Weigel et al. 2001). Binding of enoxacin to enzyme-DNA complexes constituted with resistant mutant GyrB is reduced (Yoshida et al. 1993). The crystal structures of some conformations of yeast topoisomerase II show proximity of the regions homologous to the QRDRs of GyrA and GyrB (Fass et al. 1999). In E. coli crystal structures, the basic substituents at position C7 of ciprofloxacin and moxifloxacin were shown to be facing the GyrB subunit, and they could be cross-linked to GyrB Cys466 (Mustaev et al. 2014). In addition, in another crystal structure Arg418 of Acinetobacter baumannii topoisomerase IV is in proximity to the moxifloxacin C7 basic substituent (Wohlkonig et al. 2010). Notably, resistance mutations in acidic residues in this domain of GyrB in E. coli (Asp426Asn) as well as in ParC, suggest that drug-enzyme contacts could be mediated by charge interactions (Wohlkonig et al. 2010). Thus, resistance mutations in the QRDRs of both GyrA/ParC and GyrB/ParE appear to act by reducing the affinity of quinolones for the enzyme-DNA complex. Although direct drug binding data are not yet available for mutant topoisomerase IVDNA complexes, the similarity of structures between gyrase and topoisomerase IV and the conservation of key residues predict that resistance is similarly mediated by reduced affinity for both enzyme-DNA complexes.

The magnitude of resistance caused by a single-target mutation in one of the subunits of gyrase or topoisomerase IV varies by quino- 
lone and bacterial species (Pan and Fisher 1997; Fournier et al. 2000). Because quinolone interaction with either target enzyme-DNA complex is sufficient to block cell growth and trigger cell death (Drlica and Zhao 1997), the level of susceptibility of a wild-type bacterium is determined by the more sensitive of the two target enzymes, as noted above, often gyrase in Gram-negative bacteria and topoisomerase IV in Gram-positive bacteria (Blanche et al. 1996; Pan and Fisher 1997). Thus, under quinolone selection pressure, resistance mutation in the more sensitive or primary target enzyme will generally occur first because mutation in the secondary less sensitive target enzyme alone does not have a resistance phenotype because of the dominance of the quinolone-primary target interaction (Trucksis et al. 1991; Ng et al. 1996; Breines et al. 1997). The magnitude of the increase in resistance from such a firststep mutation in the primary target is then determined by either the magnitude of the effect of the mutation on enzyme sensitivity or the intrinsic level of sensitivity of the secondary target enzyme. Thus, the level of sensitivity of the secondary target enzyme can set a cap on the magnitude of resistance conferred by mutation in the primary target enzyme. The dominance of sensitivity over resistance in the two target enzymes also implies that quinolones with similar potency against both gyrase and topoisomerase IV in an organism may require mutations in both enzymes before the mutant bacterium shows a substantial resistance phenotype (Pan and Fisher 1998, 1999; Strahilevitz and Hooper 2005). Fluoroquinolones currently in clinical use generally have differences in potency between the two target enzymes, and single target mutations produce eight- to 16 -fold increases in resistance.

Accumulating mutations in both target enzymes have been shown to cause increasing quinolone resistance. In many species, high-level quinolone resistance is generally associated with mutations in both gyrase and topoisomerase IV (Schmitz et al. 1998). In several species, Mycobacterium tuberculosis, Helicobacter pylori, and Treponema pallidum, there is no topoisomerase IV, and gyrase provides the functions of both enzymes and is the only quinolone target (Hooper 2003). Thus, selection of mutations with substantial resistance phenotypes is predicted to occur readily in these pathogens, a prediction consistent with the frequent occurrence of resistance with clinical use of quinolones without use of other active agents to treat infections with $M$. tuberculosis and $H$. pylori (Tsukamura et al. 1985; Mégraud 1998).

\section{QUINOLONE RESISTANCE BECAUSE OF DECREASED DRUG ACCESS TO TARGET ENZYMES}

Quinolones must cross the bacterial envelope to interact with their cytoplasmic gyrase and topoisomerase IV targets. Active quinolone efflux, reductions in influx, or both can decrease cytoplasmic quinolone concentrations and confer resistance. In Gram-positive bacteria, reduced diffusion across the cytoplasmic membrane has not been found to cause resistance, but active efflux transporters that include quinolones in their substrate profiles have been shown to cause low-level resistance. In contrast, in Gram-negative bacteria, reduced diffusion through outer membrane porin diffusion channels can contribute to resistance. Reduced influx often acts in concert with basal or increased expression of efflux transporters with both contributing additively to resistance (Lomovskaya et al. 1999; Li and Nikaido 2009). Quinolones themselves generally do not induce expression of efflux pumps. With the exception of plasmidmediated quinolone resistance discussed later, acquired quinolone resistance by altered drug permeation occurs largely by mutations in genes encoding regulatory proteins that control the transcription of efflux pump or porin genes (Grkovic et al. 2002). Uncommonly, mutations in efflux pump structural genes have caused changes in pump substrate profiles that add quinolones (Blair et al. 2015). The levels of quinolone resistance because of regulatory mutation and pump overexpression are often limited to about four- to eightfold increases in inhibitory concentrations, likely because of counterbalancing regulatory factors and cellular toxicities of high levels of pump overexpression. 
Altered Permeation in Gram-Positive Bacteria

In Gram-positive bacteria, the major facilitator superfamily (MFS) of transporters contains the largest number of efflux transporters that include quinolones in their substrate profiles. These efflux pumps are transporters energized by the proton gradient across the bacterial membrane and are generally antiporters with exchange of substrate and protons in opposite directions. The Nor MFS pumps of $S$. aureus have been most extensively studied ( $\mathrm{Li}$ and Nikaido 2009; Schindler et al. 2015). NorA (Ubukata et al. 1989; Yu et al. 2002), NorB (Truong-Bolduc et al. 2005), and NorC (Truong-Bolduc et al. 2006) efflux pumps cause four- to eight-fold increases in resistance to quinolones when overexpressed. NorA confers resistance to hydrophilic quinolones, such as norfloxacin and ciprofloxacin, whereas NorB and NorC each confer resistance to both hydrophilic quinolones and hydrophobic quinolones, such as sparfloxacin and moxifloxacin (Yu et al. 2002; Truong-Bolduc et al. 2005, 2006); these pumps also have structurally unrelated substrates in addition to quinolones, in keeping with broad substrate profiles of many MFS transporters. Although there are natural quinolone-like compounds (Heeb et al. 2011), it is unlikely that synthetic antibacterial quinolones are themselves the natural pump substrates, which are as yet unknown for Gram-positive quinolone resistance pumps.

Regulation of expression of these transporters is complex and involves several transcriptional regulators. MgrA, the most studied, acts as a positive regulator of nor $A$ expression and a negative regulator of nor $B$ and nor $C$ expression (Ingavale et al. 2005; Truong-Bolduc et al. 2005). Posttranslational phosphorylation of MgrA by the PknB kinase results in the loss of the ability of MgrA dimers to bind the norA promoter and an increase in their binding to the nor $B$ promoter (Truong-Bolduc et al. 2008; Truong-Bolduc and Hooper 2010). Acidic conditions alter the proportions of phosphorylated and unphosphorylated MgrA, and oxidative and aeration conditions also affect dimerization and promoter binding (Chen et al. 2006; Truong-Bolduc et al. 2011a, 2012). Thus, rela- tive levels of expression of NorA, NorB, and NorC are modified in response to a variety of environmental conditions. Notably, norB expression is selectively increased in an abscess environment in response to low-free iron conditions and contributes to fitness and bacterial survival in abscesses (Ding et al. 2008), a common form of $S$. aureus infection. The natural substrate of NorB, transport of which may contribute to improving fitness in an abscess environment, is not known. In addition, physiologic increased expression of NorB at the site of infection would suggest that susceptibility testing under clinical laboratory conditions may not fully reflect susceptibility at the site of infection.

NorG, a member of the GntR-like transcriptional regulators, can also modulate pump expression and levels of quinolone resistance; it is a direct activator of nor $A$ and nor $B$ expression but a direct repressor of nor $C$ expression (Truong-Bolduc and Hooper 2007; TruongBolduc et al. 2011b). ArlRS, a two-component regulatory system, has been shown to affect expression of norA as well (Fournier and Hooper 2000; Fournier et al. 2001). There are often hierarchies in regulatory networks, and other regulators can affect expression of MgrA and NorG. Such complex regulatory networks affecting pump expression imply the importance of modulation of pump functions in cellular physiology and may contribute to different bacterial responses to quinolones in different environments that affect pump expression.

Other MFS efflux transporters that can contribute to quinolone resistance in S. aureus include MdeA (norfloxacin and ciprofloxacin) (Huang et al. 2004), SdrM (norfloxacin) (Yamada et al. 2006), QacB(III) (norfloxacin and ciprofloxacin) (Nakaminami et al. 2010), and LmrS (gatifloxacin) (Floyd et al. 2010). MFS transporters in other Gram-positive bacteria have also been shown to include quinolones in their substrate profiles. These transporters include $\mathrm{Bmr}, \mathrm{Bmr} 3$, and Blt of B. subtilis (Klyachko et al. 1997; Ohki and Murata 1997); PmrA of Streptococcus pneumoniae (Gill et al. 1999); LmrP of Lactococcus lactis (Bolhuis et al. 1995), and Lde of Listeria monocytogenes (Godreuil et al. 2003). 
D.C. Hooper and G.A. Jacoby

In addition to the MFS transporters, lesser numbers of efflux pumps of the multiple antibiotic and toxin extrusion (MATE) and ATP-binding cassette (ABC) families have been shown to confer quinolone resistance in Gram-positive bacteria. MATE family pumps, like those of the MFS, are secondary transporters energized by the membrane electrochemical gradient. MepA confers resistance to norfloxacin, ciprofloxacin, moxifloxacin, and sparfloxacin, as well as other antimicrobials and dyes (Kaatz et al. 2006). MepA is negatively regulated by MepR, and pentamidine, a MepA substrate, reduces MepR binding to the mepA promoter, thereby increasing mepA expression (Kumaraswami et al. 2009; Schindler et al. 2013). In L. monocytogenes, the FepA MATE family pump is overexpressed in quinolone-resistant strains and is regulated by the FepR transcriptional regulator, a member of the TetR family. Mutation in FepR causes FepA overexpression and resistance to norfloxacin and ciprofloxacin (Guerin et al. 2014).

Members of the $A B C$ family of transporters are, in contrast to the other pump families discussed, energized by ATP hydrolysis. PatAB of S. pneumoniae (norfloxacin and ciprofloxacin) (Boncoeur et al. 2012), SatAB of S. suis (norfloxacin and ciprofloxacin) (Escudero et al. 2011), and LmrA of L. lactis (ciprofloxacin and ofloxacin) (Poelarends et al. 2000; Putman et al. 2000) all have been shown to confer resistance to some quinolones.

\section{ALTERED PERMEATION IN GRAM-NEGATIVE BACTERIA}

In Gram-negative bacteria, the majority of efflux pumps that can effect quinolone resistance are members of the resistance-nodulationdivision (RND) superfamily ( $\mathrm{Li}$ et al. 2015). The RND pumps are secondary antiporters composed of a pump protein localized in the cytoplasmic membrane, an outer membrane channel protein, and a membrane fusion protein that links the pump and the outer membrane protein (Du et al. 2014). Some outer membrane components may link to more than one pump-fusion protein pair, enabling export of substrates across both inner and outer membranes (Li and Nikaido 2009). The beststudied systems have been in E. coli and Pseudomonas aeruginosa.

In E. coli, the AcrAB-TolC pump complex has been extensively studied. Crystal structures of the complex have revealed a trimer of AcrB pump monomers that rotate around a central axis perpendicular to the membrane, with each monomer as its rotation position changes assuming a different conformation mediating different steps in substrate binding and extrusion through the channel (Nikaido and Takatsuka 2009). Substrates enter the vestibule of AcrB from the periplasmic space between the inner and outer membranes or the outer leaflet of the inner membrane. Binding sites for ciprofloxacin and other substrates of diverse chemical types have been identified in the central cavity of the periplasmic domain of AcrB (Yu et al. 2003, 2005; Li and Nikaido 2004). Fluoroquinolones, which are zwitterionic, are presumed to cross the outer membrane through OmpF and OmpC porin diffusion channels, down-regulation or mutation of which may amplify resistance. Mutations in the MarR regulator can result in both an increase in $a c r B$ expression as well as a decrease in ompF expression, dually contributing to quinolone resistance (Alekshun and Levy 1999). Mutations in the E. coli SoxRS (Miller et al. 1994; Chou et al. 1998) and Rob (Jair et al. 1996) regulons can also effect resistance to fluoroquinolones in part related to reductions in $\mathrm{OmpF}$ and in a manner that is dependent on AcrAB-TolC. Expression of AcrAB-TolC also confers resistance to bile salts and is induced by bile salts, likely one of its natural substrates (Rosenberg et al. 2003). Thus, AcrAB supports the ability of $E$. coli to survive in its natural habitat, the lower gastrointestinal tract, and perhaps only incidentally affects quinolone susceptibility.

In $P$. aeruginosa, the OprF porin channel has permeability a 100 -fold lower than that of OmpF in E. coli (Nikaido et al. 1991), contributing to its intrinsic resistance to quinolones and other antimicrobial agents relative to E. coli and other enteric bacteria. The MexABOprM efflux pump, a RND pump similar in 
structure to AcrAB-TolC and expressed in wildtype strains, acts in concert with the low permeability of OprF to augment the intrinsic level of resistance of $P$. aeruginosa to fluoroquinolones ( $\mathrm{Li}$ et al. 2000b). Mutations in mexA and $o p r M$ cause increased uptake of norfloxacin and increased susceptibility to fluoroquinolones (Poole et al. 1996b). Increased expression of MexAB-OprM because of mutations in the MexR negative regulator causes increased resistance to ciprofloxacin and nalidixic acid, and mexR mutants can be selected with exposure to fluoroquinolones (Poole et al. 1993). $P$. aeruginosa also has three other efflux pump systems that include quinolones in their substrate profiles, MexCD-OprJ, MexEF-OprN, and MexXY-OprM (Masuda et al. 2000). These pumps vary in expression levels in wild-type strains ( $\mathrm{Li}$ et al. 2000a), but resistant mutants overexpressing these pumps can be selected with fluoroquinolones and other antimicrobial substrates (Köhler et al. 1997b). Mutation in the $\mathrm{NfxB}$ repressor, which is encoded upstream of the mexCD-oprJ operon, causes increased expression of MexCD-OprJ and resistance to fluoroquinolones (Poole et al. 1996a). Mutation in $n f x C$ results in overexpression of MexEF-OprN, but the exact regulatory mechanism is not yet known (Köhler et al. 1997a). Mutations in the global regulator MvaT, which affects quorum sensing and virulence, also causes increased expression of mexEF-oprM and resistance to norfloxacin (Westfall et al. 2006). Expression of both MexEF-OprN and MexCD-OprJ vary inversely with the level of expression of MexABOprM, but the mechanisms underlying this property have not yet been elucidated ( $\mathrm{Li}$ et al. 2000a). Mutations in the MexZ repressor cause increased expression of MexXY-OprM and resistance to fluoroquinolones, aminoglycosides, and other pump substrates (Matsuo et al. 2004; Hay et al. 2013). Specific quinolones differ in the mutations they most commonly select (Köhler et al. 1997b). Most quinolones in clinical use have a fluorine at position 6 and a positively charged substituent at position 7 (e.g., norfloxacin, ciprofloxacin, levofloxacin, and moxifloxacin) and tend to select $n f x B$-type mutants. In contrast, quinolones lacking a positive charge at position 7 (e.g., nalidixic acid) often select mexR and $n f x C$-type mutants, differences presumably reflecting differences in the resistance profiles of the regulated pumps.

Additional RND pumps that cause quinolone resistance have been found in a broad range of Gram-negative bacteria. Salmonella spp. (Baucheron et al. 2002) and Enterobacter aerogenes (Pradel and Pagès 2002) have AcrAB homologs, and their increased expression has been associated with quinolone resistance. The CmeABC RND pump of Campylobacter jejuni contributes to the resistance of mutants selected with enrofloxacin, a veterinary quinolone similar to ciprofloxacin (Lin et al. 2002; Luo et al. 2003). In Klebsiella pneumoniae, the OqxABTolC pump is encoded on the chromosome (Kim et al. 2009b) and was originally identified in E. coli isolates from pigs as a cause of plasmidmediated resistance to olaquindox, a growth promotant used in swine production; it also confers resistance to quinolones.

Among nonenteric bacteria, in A. baumannii, the AdeIJK RND pump (Fernando et al. 2014) is constitutively expressed and its broad resistance profile includes fluoroquinolones. In addition, overexpression of the AdeABC and AdeFGH RND pumps because of mutation in their respective regulators, AdeRS, a two-component sensor-regulator system, and AdeL, a LysR family transcriptional regulator, also confer a similarly broad resistance profile containing fluoroquinolones (Yoon et al. 2013, 2015). In Stenotrophomonas maltophilia, the SmeDEF pump (Alonso et al. 2000; Zhang et al. 2001) has been shown to contribute to quinolone resistance based on pump knockout mutants with increased susceptibility, resistant isolates with increased pump gene expression, and its ability to confer resistance when overexpressed in E. coli.

Non-RND efflux pumps are much less common in Gram-negative bacteria. A few cases MFS and MATE pumps associated with quinolone resistance have been identified. Among MFS pumps, in E. coli, EmrAB-TolC, an MFS pump that functions in tripartite structure like the RND pumps, is negatively regulated by EmrR and confers resistance to nalidixic acid 
D.C. Hooper and G.A. Jacoby

but not fluoroquinolones (Lomovskaya et al. 1995). MdfA, originally termed CmlA, confers resistance to both chloramphenicol and fluoroquinolones (Yang et al. 2003). MATE pumps include the NorM pump, which can confer quinolone resistance in Vibrio parahaemolyticus (Morita et al. 2000), and in anaerobic Gramnegative bacteria the NorA pump of Bacteroides fragilis (Miyamae et al. 1998) and the BexA pump of B. thetaiotaomicron (Miyamae et al. 2001), which have been shown to efflux fluoroquinolones.

There are additional examples in both Gram-positive and Gram-negative bacteria in which there is evidence of efflux in quinoloneresistant isolates determined by either reduction in resistance with addition of a broad efflux pump inhibitor or reduced quinolone accumulation in resistant cells, but the contributing pump or its regulator have not been identified (Li and Nikaido 2009; Nikaido and Takatsuka 2009). Information on efflux mechanisms and resistance in $>50$ bacterial species has recently been extensively reviewed ( $\mathrm{Li}$ and Nikaido 2009; $\mathrm{Li}$ et al. 2015) and is beyond the scope of this review. Thus, efflux-mediated resistance to quinolones and many other antimicrobials is widespread. The broad substrate profiles of these pumps link quinolone resistance to multidrug resistance and constitute mechanisms by which use of non-quinolone antimicrobials can also increase quinolone resistance. A similar linkage to multidrug resistance occurs with plasmid-mediated quinolone resistance, which is discussed in the next section.

\section{PLASMID-MEDIATED QUINOLONE RESISTANCE}

Plasmid-mediated quinolone resistance (PMQR) was reported in 1998, 31 years after nalidixic acid began to be used clinically and 12 years after modern fluoroquinolones were approved for use (Martínez-Martínez et al. 1998). Transferable nalidixic acid resistance had been sought unsuccessfully in the 1970s (Burman 1977), and plasmid-mediated resistance was thought unlikely to exist because quinolones are synthetic compounds, and adequate resistance can arise by chromosomal mutations (Courvalin 1990). The first PMQR was discovered in a multiresistant urinary isolate of $K$. pneumoniae from Alabama that could transfer low-level ciprofloxacin resistance to a variety of Gram-negative bacteria. When the responsible gene, named $q n r$ and later qnrA, was cloned and sequenced facilitating its identification by PCR (Tran and Jacoby 2002), qnr was soon found at low-frequency on plasmids in Gram-negative isolates around the world. One qnrA plasmid from Shanghai conferred an unusually high-level of resistance and further study disclosed that it carried an additional mechanism for PMQR, namely, modification of certain quinolones by a variant of the common aminoglycoside-modifying acetyltransferase AAC $\left(6^{\prime}\right)$-Ib (Robicsek et al. 2006). A third mechanism for PMQR was the discovery of two plasmid-encoded quinolone efflux pumps: OqxAB and QepA (Sorensen et al. 2003, Périchon et al. 2007; Yamane et al. 2007). In the last decade, $P M Q R$ genes have been found in bacterial isolates worldwide. They reduce bacterial susceptibility to quinolones, usually not to the level of clinical nonsusceptibility, but facilitate the selection of mutants with higher level quinolone resistance and promote treatment failure.

\section{Qnr Structure and Function}

Cloning and sequencing qnrA revealed that it encoded a 218-residue protein with a tandemly repeating unit of five amino acids that indicated membership in the many thousand-member pentapeptide repeat family of proteins (Tran and Jacoby 2002). Further searches led to the discovery of related genes for plasmid-mediated pentapeptide repeat proteins qnrS (Hata et al. 2005), qnrB (Jacoby et al. 2006), qnrC (Wang et al. 2009), qnrD (Cavaco et al. 2009), and qnrVC (Fonseca and Vicente 2013), as well as chromosomal qnr genes in bacteria from a variety of clinical and environmental sources (Rodríguez-Martínez et al. 2008a; Sánchez et al. 2008). These new $q n r$ genes generally differed by $35 \%$ or more in sequence from qnrA and each other. Allelic varieties that differ by $10 \%$ or less have been described in almost all families: currently seven 
for QnrA, 78 for QnrB, one for QnrC, two for QnrD, nine for QnrS, and six for QnrVC (see lahey.org/qnrstudies) (Jacoby et al. 2008).

The first pentapeptide-repeat protein to have its structure determined by X-ray crystallography was MfpA, which is encoded on the chromosome of $M$. smegmatus and other mycobacteria (Hegde et al. 2005) and implicated in quinolone resistance (Montero et al. 2001). MfpA is a dimer, linked carboxyl terminus to carboxyl terminus, and folded into a righthanded quadrilateral $\beta$ helix with size, shape, and charge mimicking the B-form of DNA and just the size to fit into the cationic $G$ segment DNA-binding saddle of DNA gyrase and topoisomerase IV. In vitro, MfpA inhibits DNA supercoiling by gyrase and, although it fails to block gyrase inhibition by quinolone, it can still confer quinolone resistance to whole cells by competing with DNA to reduce the number of lethal double-strand breaks produced by quinolone (Hegde et al. 2005).

As shown first with purified QnrA1 (Tran and Jacoby 2002), and subsequently with plasmid-encoded QnrB1 (Jacoby et al. 2006) and QnrS1 (Tavio et al. 2014), and with chromosomally encoded AhQnr from Aeromonas hydrophila (Xiong et al. 2011) and EfsQnr from E. faecalis (Hegde et al. 2011), Qnr proteins do protect DNA gyrase from quinolone inhibition and only inhibit the enzyme at high concentration. Like MfpA, they form rod-like dimers but have additional structural features. The structure of QnrB1 is shown in Figure 1. The quadrilateral $\beta$-helix is stabilized by interactions between the middle, usually hydrophobic, amino acid (i) of the pentapeptide repeat and the first polar or hydrophobic residue (i-2), which point inward, whereas the remaining amino acids (i-1, i+1, i+2) are oriented outward, forming a generally anionic surface. Hydrogen bonding between backbone atoms of neighboring coils stabilizes the helix.

The monomers of QnrB1 and AhQnr have projecting loops of eight and 12 amino acids that are important for their activity. Deletion of the small A loop reduces quinolone protection, whereas deletion of the larger B loop or both loops destroys protective activity (Vetting et al. 2011; Xiong et al. 2011). Removal of even a single amino acid in the larger loop compromises protection. Other essential residues in QnrB are found in pentapeptide repeat positions $\mathrm{i}$ and $\mathrm{i}-2$, in which alanine substitution for the native amino acid eliminates protection as does deletion of $>10$ amino acids at the amino terminus or as few as three amino acids from the dimerization module at the carboxyl terminus (Jacoby et al. 2013). EfsQnr lack loops, but EfsQnr differs from MfpA in having a 25-amino-acid flexible extension required for full protective activity (Hegde et al. 2011).

In vitro, more Qnr is required to protect DNA gyrase as the inhibiting concentration of quinolone is increased (Tran and Jacoby 2002). In a gel-displacement assay (Tran et al. 2005) or bacterial two-hybrid system (Kim et al. 2015), Qnr binds to both gyrase holoenzyme and its $\mathrm{A}$ and B subunits. Binding to GyrA is reduced by the same amino- and carboxy-terminal and loop B deletions in QnrB that destroy its protective activity, whereas subinhibitory concentrations of ciprofloxacin reduce binding to GyrA but not to GyrB, suggesting that Qnr protects gyrase by blocking access of quinolone to GyrA sites essential for its lethal action.

Many naturally occurring antibiotics and synthetic agents also target DNA gyrase. Qnr protects against compounds with a somewhat quinolone-like structure (Jacoby et al. 2015), for example, 2-pyridone (Flamm et al. 1995), quinazoline-2,4-dione (Huband et al. 2007), or spiropyrimidinetrione (Kern et al. 2011), so it is not strictly quinolone-specific. Qnr, however, does not block agents acting on the GyrB subunit, and it also does not block simocyclinone D8, which, like quinolones, binds to the amino terminus of GyrA and blocks DNA binding (Hearnshaw et al. 2014).

\section{Qnr ORIGIN}

Qnr homologs can be found encoded on the chromosome of many Gram-positive as well as Gram-negative bacteria, including species of Bacillus, Enterococcus, Listeria, and Mycobacterium, and anaerobes such as Clostridium difficile and Clostridium perfringens (Rodríguez-Martí- 
D.C. Hooper and G.A. Jacoby

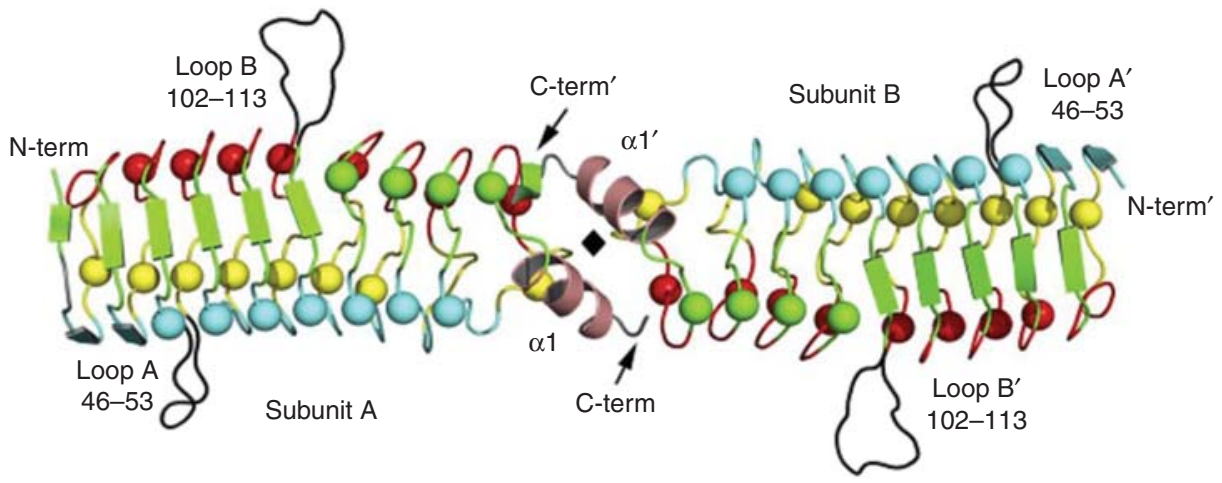

\begin{tabular}{|c|c|c|c|c|c|}
\hline & Face1 & Face2 & Face3 & \multicolumn{2}{|l|}{ Face4 } \\
\hline N-ter & $i^{-2} i^{-1} i i^{+1} i^{+2}$ & $i^{-2} i^{-1} i i^{+1} i^{+2}$ & $i^{-2} i^{-1} i i^{+1} i^{+2}$ & $i^{-2} i^{-1} i i^{+1} i^{+2}$ & \\
\hline Coil0 & M A & $\mathrm{L} A \mathrm{~L} V \mathrm{G}$ & 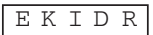 & NR F T G & 17 \\
\hline Coil1 & $E K I E N$ & $S T F F N$ & C D F S G & $A D \perp S G$ & 37 \\
\hline Coil2 & $T E F I G$ & $C Q F$ & $C \quad N \quad F \quad S \quad R$ & A $M L K \quad \mathrm{D}$ & 63 \\
\hline Coil3 & A I F K S & $C D \perp S M$ & A D F R N & $S S A L G$ & 83 \\
\hline Coil4 & I E I R H & $C R A Q G$ & $A D F R G$ & A S F * * & 101 \\
\hline Coil5 & A Y I T N & $T N L S Y$ & $A \quad N \quad F \quad S \quad K$ & $\mathrm{~V} V \mathrm{~L} E \mathrm{~K}$ & 133 \\
\hline Coil6 & $C E L W E$ & $N R W I G$ & $A Q \vee L G$ & A T F S G & 153 \\
\hline Coil7 & $S D L S G$ & $G \in F S T$ & $F \quad D W R A$ & $\mathrm{~A} N \mathrm{~N} \quad \mathrm{~T} \mathrm{H}$ & 173 \\
\hline Coil8 & C D L T N & $S E L G D$ & L D I R G & $\mathrm{V} D \mathrm{~L} Q \mathrm{G}$ & 193 \\
\hline Coil9 & $\mathrm{V} K \mathrm{~K} L \mathrm{D} N$ & YQASL L & ERL GIAVI & & 214 \\
\hline & & & & & \\
\hline
\end{tabular}

Figure 1. The rod-like structure of the QnrB1 dimer is shown (above) with the sequence of the monomer (below). The sequence is divided into four columns representing the four faces of the right-handed quadrilateral $\beta$-helix. Face names and color are shown at the top along with the naming convention for the five residues of the pentapeptide repeats. Loops A and B are indicated by one and two asterisks, respectively, with their sequences indicated below and the loops shown as black traces on the diagram. The carboxy-terminal $\alpha$-helix is colored salmon. The molecular twofold symmetry is indicated with a black diamond. Type II turn containing faces are shown as spheres and type IV-containing faces as strands. N-term, Amino terminal; C-term, carboxy terminal. (From Jacoby et al. 2014; reproduced, with permission, from the authors.)

nez et al. 2008b; Sánchez et al. 2008; Boulund et al. 2012; Jacoby and Hooper 2013). Aquatic bacteria are especially well represented, including species of Aeromonas, Photobacterium, Shewanella, and Vibrio (Poirel et al. 2005a,b). QnrA1 is 98\% identical to the chromosomally determined Qnr of Shewanella algae (Poirel et al. 2005a). QnrS1 is 97\% identical to Qnr from Vibrio parahemolyticus S022 (GenBank accession number WP_029823919) or Vibrio mytili (GenBank WP_041155100), and QnrC is 97\% identical to Qnr in V. parahemolyticus S145 (GenBank WP_025518018). QnrB homologs, on the other hand, are encoded on the chromosome of members of the Citrobacter freundii complex (Jacoby et al. 2011; Ribeiro et al. 2015). The small, nonconjugative plasmids that carry $q n r D$ are especially likely to be found in Proteeae, such as Proteus mirabilis, P. vulgaris, and Providencia rettgeri and may have originated there (Guillard et al. 2012, 2014; Zhang et al. 2013).

The worldwide distribution of $q n r$ suggests an origin well before quinolones were discovered. Indeed, $q n r B$ genes and pseudogenes have been discovered on the chromosome of C. freundii strains collected in the 1930s (Saga et al. 2013). What the native function of Qnr may have been is an as-yet unanswered question. 
$\mathrm{AAC}\left(6^{\prime}\right)-\mathrm{Ib}-\mathrm{Cr}$

$\mathrm{AAC}\left(6^{\prime}\right)-\mathrm{Ib}-\mathrm{cr}$ is a bifunctional variant of a common acetyltransferase, providing resistance to such aminoglycosides as amikacin, kanamycin, and tobramycin, but also able to acetylate those fluoroquinolones with an amino nitrogen on the piperazinyl ring such as ciprofloxacin and norfloxacin (Robicsek et al. 2006). Compared with other AAC $\left(6^{\prime}\right)$-Ib enzymes, the -cr variant has two unique amino acid substitutions-Trp102Arg and Asp179Tyr-both of which are required for quinolone acetylating activity. Models of enzyme action suggest that the Asp179Tyr replacement is particularly important in permitting $\pi$-stacking interactions with the quinolone ring to facilitate quinolone binding. The role of Trp102Arg is to position the Tyr face for optimal interaction (Vetting et al. 2008) or to hydrogen bond to keto or carboxyl groups of the quinolone to fix it in place (Maurice et al. 2008). The $a a c\left(6^{\prime}\right)-I b-c r$ gene is usually found in a cassette as part of an integron in a multiresistance plasmid, which may contain other PMQR genes. Several alleles have been described (Quiroga et al. 2015). The gene has been found worldwide in a variety of Enterobacteriaceae and even in $P$. aeruginosa (Ogbolu et al. 2011). Association with extended spectrum $\beta$-lactamase (ESBL) CTX-M-15 is particularly common (Oteo et al. 2009; Sabtcheva et al. 2009).

\section{OqxAB AND QepA}

OqxAB was first identified as a plasmid-mediated efflux pump conferring resistance to the olaquindox, a food additive enhancing growth in pigs (Sorensen et al. 2003) and later shown to confer resistance to ciprofloxacin and norfloxacin as well as other antimicrobials, including chloramphenicol, nitrofurantoin, and trimethoprim (Hansen et al. 2007; Ho et al. 2016). Genes for $\operatorname{oq} x A B$ are commonly found on the chromosome of $K$. pneumoniae and Enterobacter spp. but are expressed at a much higher level when captured on plasmids, often in association with the IS26 mobilizing element (Rodríguez-Martínez et al. 2013; Wong et al. 2015). In a study of fecal samples from animals and farmworkers in China, where olaquindox is used, $40 \%$ of E. coli isolated from animals and $30 \%$ from humans carried plasmid-mediated $o q x A B$, making it much more common than other types of PMQR in this setting (Zhao et al. 2010).

The QepA efflux pump was reported in 2007 by investigators in Japan and France on plasmids in clinical isolates of E. coli often associated with aminoglycoside resistance because of ribosomal methylase $r m t B$ (Périchon et al. 2007; Yamane et al. 2007). It has subsequently been found worldwide (Habeeb et al. 2014; Zhao et al. 2015).

\section{QUINOLONE RESISTANCE PLASMIDS}

Genes for quinolone resistance have been found on plasmids varying in size and incompatibility specificity, indicating that the spread of multiple plasmids has been responsible for the dissemination of this resistance around the world and that plasmid acquisition of qnr and other quinolone resistance determinants has occurred independently multiple times. A mobile or transposable element is almost invariably associated with qnr genes, especially ISCR1 and IS26. $q n r D$ and $q n r S 2$ are located within mobile insertion cassettes, elements with bracketing inverted repeats but lacking a transposase (Picão et al. 2008; Guillard et al. 2014), whereas qnrVC is so far the only qnr gene located in a cassette with a linked attC site (Fonseca et al. 2008; Belotti et al. 2015).

$q n r$ genes are usually found in multiresistance plasmids linked to other resistance determinants. $\beta$-lactamase genes, including genes for ESBLs, AmpC enzymes, and carbapenemases, have been conspicuously common (Jacoby et al. 2014).

PMQR genes have been found in a variety of Enterobacteriaceae, especially E. coli and species of Enterobacter, Klebsiella, and Salmonella (Jacoby et al. 2014). They have rarely been found in nonfermenters but have occasionally been reported in $P$. aeruginosa and A. baumannii. qnr genes are also found in a variety of Gram-positive organisms but are chromosomal and not plasmid-mediated. The earliest known qnr out- 
D.C. Hooper and G.A. Jacoby

side of Citrobacter spp. dates from 1988 (Jacoby et al. 2009). Studies in the last decade suggest that the prevalence of PMQR is increasing (Kim et al. 2009a). In a recent study of $>500$ isolates of E. coli from 30 county hospitals in China, $37.3 \%$ carried at least one PMQR gene, including $19.7 \%$ with aac $\left(6^{\prime}\right)-I b-c r, 14.4 \%$ with qepA, $3.8 \%$ with oqxAB, and $3.7 \%$ with $q n r$ (Zhao et al. 2015).

\section{RESISTANCE BECAUSE OF PMQR DETERMINANTS}

Table 2 shows the effect on susceptibility of a common E. coli host of various PMQR genes. $q n r$ alleles decrease ciprofloxacin or levofloxacin susceptibility 30 -fold to a level similar to that of the common Ser83Leu GyrA mutation but have much less effect on nalidixic acid resistance. The other PMQR genes reduce susceptibility even less but with more specificity. Levofloxacin and nalidixic acid are unaffected by $\operatorname{AAC}\left(6^{\prime}\right)$ Ib-cr because they lack the C7 amino target for acetylation, and QepA affects ciprofloxacin susceptibility more than that of the other quinolones (Périchon et al. 2007). By themselves none reaches the CLSI breakpoint for loss of susceptibility. In combination, however, they may do so, and all facilitate selection of higher-level quinolone resistance (Martínez-Martínez et al. 1998; Robicsek et al. 2006; RodríguezMartínez et al. 2007).

From a PMQR-free E. coli strain selection on ciprofloxacin at $\geq 3$ times minimum inhibitory concentration (MIC) commonly yields mutants with alterations in the QRDR of gyrA. Surprisingly, gyrase mutants are rarely selected from the same strain carrying $q n r$ (Cesaro et al. 2008). Rather, mutants have increased expression of $a c r A B, m d t E F$, or $y d h E$ pumps, which efflux quinolones, or alterations in genes of lipopolysaccharide core biosynthesis, which may reduce quinolone entry via reduction in porin expression (Vinué et al. 2015).

Despite the modest effect of PMQR genes on susceptibility, their presence makes infections in animal models harder to treat (Rodríguez-Martínez et al. 2008a; Jakobsen et al. 2012), and there is some evidence for poorer outcomes from human infections with qnr containing pathogens (Chong et al. 2010; Liao et al. 2013).

\section{SUMMARY}

Resistance to quinolones has increased to substantial levels, despite these agents being synthetic and having two essential bacterial targets. The microbial resistance has been affected by an impressive diversity of mechanisms that have linked quinolone resistance to multidrug resistance, compounding the current public health and medical challenges of broadly resistant bacteria. Dual topoisomerase targets with differing sensitivities to many quinolones in clinical use create a pathway for additive mutational resistance to high levels. This core target-based resistance has been further supplemented and

Table 2. Minimum inhibitory concentrations (MICs) produced in E. coli

\begin{tabular}{|c|c|c|c|}
\hline \multirow[b]{2}{*}{ E. coli strain } & \multicolumn{3}{|c|}{$\operatorname{MIC}(\mu \mathrm{g} / \mathrm{ml})$} \\
\hline & Ciprofloxacin & Levofloxacin & Nalidixic acid \\
\hline $\mathrm{J} 53$ & 0.008 & 0.015 & 4 \\
\hline J53 gyrA S83L & 0.25 & 0.5 & $\geq 512$ \\
\hline J53 pMG252 (qnrA1) & 0.25 & 0.5 & 16 \\
\hline J53 pMG299 (qnrB1) & 0.25 & 0.5 & 16 \\
\hline J53 pMG306 (qnrS1) & 0.25 & 0.38 & 16 \\
\hline J53 pMG320 (aac $\left.\left(6^{\prime}\right)-I b-c r\right)$ & 0.06 & 0.015 & 4 \\
\hline J53 pAT851 (qерA) & 0.064 & 0.032 & 4 \\
\hline CLSI susceptibility breakpoint & $\leq 1.0$ & $\leq 2.0$ & $\leq 16$ \\
\hline
\end{tabular}

From Jacoby et al. 2014.

MIC, Minimum inhibitory concentration. 
facilitated by more insidious low-level resistance. This low-level resistance has come from both overexpression of native multidrug efflux pumps as well as the unanticipated emergence of multiple mechanisms of plasmid-mediated quinolone resistance, which may not be readily detected in clinical laboratories but can facilitate selection of higher-level resistance and adds a plasmid linkage to multidrug resistance.

\section{ACKNOWLEDGMENTS}

This work is supported by Grants R01 AI057576 (to D.C.H and G.A.J.), R37 AI023988 (to D.C.H.), and P01 AI083214 (to D.C.H.) from the U.S. Public Health Service, National Institutes of Health.

\section{REFERENCES}

Aldred KJ, McPherson SA, Wang P, Kerns RJ, Graves DE, Turnbough CL Jr, Osheroff N. 2012. Drug interactions with Bacillus anthracis topoisomerase IV: Biochemical basis for quinolone action and resistance. Biochemistry 51: 370-381.

Aldred KJ, Kerns RJ, Osheroff N. 2014. Mechanism of quinolone action and resistance. Biochemistry 53: 1565-1574.

Alekshun MN, Levy SB. 1999. The mar regulon: Multiple resistance to antibiotics and other toxic chemicals. Trends Microbiol 7: 410-413.

Alonso A, Martinez JL. 2000. Cloning and characterization of SmeDEF, a novel multidrug efflux pump from Stenotrophomonas maltophilia. Antimicrob Agents Chemother 44: 3079-3086.

Baucheron S, Imberechts H, Chaslus-Dancla E, Cloeckaert A. 2002. The AcrB multidrug transporter plays a major role in high-level fluoroquinolone resistance in Salmonella enterica serovar typhimurium phage type DT204. Microb Drug Resist 8: 281-289.

Bax BD, Chan PF, Eggleston DS, Fosberry A, Gentry DR, Gorrec F, Giordano I, Hann MM, Hennessy A, Hibbs M, et al. 2010. Type IIA topoisomerase inhibition by a new class of antibacterial agents. Nature 466: 935-940.

Belotti PT, Thabet L, Laffargue A, Andre C, CoulangeMayonnove L, Arpin C, Messadi A, M'Zali F, Quentin C, Dubois V. 2015. Description of an original integron encompassing $b l a_{\mathrm{VIM}-2}, q n r V C 1$ and genes encoding bacterial group II intron proteins in Pseudomonas aeruginosa. J Antimicrob Chemother 70: 2237-2240.

Blair JM, Bavro VN, Ricci V, Modi N, Cacciotto P, Kleinekathfer U, Ruggerone P, Vargiu AV, Baylay AJ, Smith HE, et al. 2015. AcrB drug-binding pocket substitution confers clinically relevant resistance and altered substrate specificity. Proc Natl Acad Sci 112: 3511-3516.

Blanche F, Cameron B, Bernard FX, Maton L, Manse B, Ferrero L, Ratet N, Lecoq C, Goniot A, Bisch D, et al.
1996. Differential behaviors of Staphylococcus aureus and Escherichia coli type II DNA topoisomerases. Antimicrob Agents Chemother 40: 2714-2720.

Bolhuis H, Poelarends G, Van Veen HW, Poolman B, Driessen AJM, Konings WN. 1995. The lactococcal lmrP gene encodes a proton motive force-dependent drug transporter. J Biol Chem 270: 26092-26098.

Boncoeur E, Durmort C, Bernay B, Ebel C, Di Guilmi AM, Croize J, Vernet T, Jault JM. 2012. PatA and PatB form a functional heterodimeric $\mathrm{ABC}$ multidrug efflux transporter responsible for the resistance of Streptococcus pneumoniae to fluoroquinolones. Biochemistry 51: 7755-7765.

Boulund F, Johnning A, Pereira MB, Larsson DG, Kristiansson E. 2012. A novel method to discover fluoroquinolone antibiotic resistance (qnr) genes in fragmented nucleotide sequences. BMC Genomics 13: 695.

Breines DM, Ouabdesselam S, Ng EY, Tankovic J, Shah S, Soussy CJ, Hooper DC. 1997. Quinolone resistance locus $n f x D$ of Escherichia coli is a mutant allele of parE gene encoding a subunit of topoisomerase IV. Antimicrob Agents Chemother 41: 175-179.

Burman LG. 1977. Apparent absence of transferable resistance to nalidixic acid in pathogenic Gram-negative bacteria. J Antimicrob Chemother 3: 509-516.

Cavaco LM, Hasman H, Xia S, Aarestrup FM. 2009. qnrD, a novel gene conferring transferable quinolone resistance in Salmonella enterica serovar Kentucky and Bovismorbificans strains of human origin. Antimicrob Agents Chemother 53: 603-608.

Cesaro A, Bettoni RR, Lascols C, Merens A, Soussy CJ, Cambau E. 2008. Low selection of topoisomerase mutants from strains of Escherichia coli harbouring plasmidborne qur genes. J Antimicrob Chemother 61: 1007-1015.

Chen PR, Bae T, Williams WA, Duguid EM, Rice PA, Schneewind $\mathrm{O}, \mathrm{He}$ C. 2006. An oxidation-sensing mechanism is used by the global regulator MgrA in Staphylococcus aureus. Nat Chem Biol 2: 591-595.

Chong YP, Choi SH, Kim ES, Song EH, Lee EJ, Park KH, Cho OH, Kim SH, Lee SO, Kim MN, et al. 2010. Bloodstream infections caused by qnr-positive Enterobacteriaceae: Clinical and microbiologic characteristics and outcomes. Diagn Microbiol Infect Dis 67: 70-77.

Chou JH, Greenberg JT, Demple B. 1998. Postranscriptional repression of Escherichia coli OmpF protein in response to redox stress: Positive control of the micF antisense RNA by the soxRS locus. J Bacteriol 175: 1026-1031.

Courvalin P. 1990. Plasmid-mediated 4-quinolone resistance: A real or apparent absence? Antimicrob Agents Chemother 34: 681-684.

Ding Y, Onodera Y, Lee JC, Hooper DC. 2008. NorB, an efflux pump in Staphylococcus aureus MW2, contributes to bacterial fitness in abscesses. J Bacteriol 190: 71237129.

Domagala JM, Hagen SE. 2003. Structure-activity relationships of the quinolone antibacterials in the new millennium: Some things change and some do not. In Quinolone antimicrobial agents, 3rd ed. (ed. Hooper DC, Rubinstein E), pp. 3-18. ASM, Washington, DC.

Drlica K, Zhao XL. 1997. DNA gyrase, topoisomerase IV, and the 4-quinolones. Microbiol Rev 61: 377-392. 
D.C. Hooper and G.A. Jacoby

Drlica K, Malik M, Kerns RJ, Zhao X. 2008. Quinolonemediated bacterial death. Antimicrob Agents Chemother 52: $385-392$.

Drlica K, Hiasa H, Kerns R, Malik M, Mustaev A, Zhao X. 2009. Quinolones: Action and resistance updated. Curr Top Med Chem 9: 981-998.

Du D, Wang Z, James NR, Voss JE, Klimont E, Ohene-Agyei T, Venter H, Chiu W, Luisi BF. 2014. Structure of the AcrAB-TolC multidrug efflux pump. Nature 509: 512 515.

Escudero JA, San MA, Gutierrez B, Hidalgo L, La Ragione RM, AbuOun M, Galimand M, Ferrandiz MJ, Dominguez L, de la Campa AG, et al. 2011. Fluoroquinolone efflux in Streptococcus suis is mediated by SatAB and not by SmrA. Antimicrob Agents Chemother 55: 5850-5860.

Fass D, Bogden CE, Berger JM. 1999. Quaternary changes in topoisomerase II may direct orthogonal movement of two DNA strands. Nature Struct Biol 6: 322-326.

Fernando DM, Xu W, Loewen PC, Zhanel GG, Kumar A. 2014. Triclosan can select for an AdeIJK-overexpressing mutant of Acinetobacter baumannii ATCC 17978 that displays reduced susceptibility to multiple antibiotics. Antimicrob Agents Chemother 58: 6424-6431.

Flamm RK, Vojtko C, Chu DT, Li Q, Beyer J, Hensey D, Ramer N, Clement JJ, Tanaka SK. 1995. In vitro evaluation of ABT-719, a novel DNA gyrase inhibitor. Antimicrob Agents Chemother 39: 964-970.

Floyd JL, Smith KP, Kumar SH, Floyd JT, Varela MF. 2010. LmrS is a multidrug efflux pump of the major facilitator superfamily from Staphylococcus aureus. Antimicrob Agents Chemother 54: 5406-5412.

Fonseca EL, Vicente AC. 2013. Epidemiology of qnrVC alleles and emergence out of the Vibrionaceae family. J Med Microbiol 62: 1628-1630.

Fonseca EL, Dos Santos Freitas F, Vieira VV, Vicente AC. 2008. New qnr gene cassettes associated with superintegron repeats in Vibrio cholerae O1. Emerg Infect Dis 14: 1129-1131.

Fournier B, Hooper DC. 2000. A new two-component regulatory system involved in adhesion autolysis, and extracellular proteolytic activity of Staphylococcus aureus. J Bacteriol 182: 3955-3964.

Fournier B, Zhao X, Lu T, Drlica K, Hooper DC. 2000. Selective targeting of topoisomerase IV and DNA gyrase in Staphylococcus aureus: Different patterns of quinolone-induced inhibition of DNA synthesis. Antimicrob Agents Chemother 44: 2160-2165.

Fournier B, Klier A, Rapoport G. 2001. The two-component system ArlS-ArlR is a regulator of virulence gene expression in Staphylococcus aureus. Mol Microbiol 41: 247261.

Gensberg K, Jin YF, Piddock LJ. 1995. A novel gyrB mutation in a fluoroquinolone-resistant clinical isolate of Salmonella typhimurium. FEMS Microbiol Lett 132: 57-60.

Gill MJ, Brenwald NP, Wise R. 1999. Identification of an efflux pump gene, $p m r A$, associated with fluoroquinolone resistance in Streptococcus pneumoniae. Antimicrob Agents Chemother 43: 187-189.

Godreuil S, Galimand M, Gerbaud G, Jacquet C, Courvalin P. 2003. Efflux pump Lde is associated with fluoroquin- olone resistance in Listeria monocytogenes. Antimicrob Agents Chemother 47: 704-708.

Grkovic S, Brown MH, Skurray RA. 2002. Regulation of bacterial drug export systems. Microbiol Mol Biol Rev 66: $671-701$.

Guerin F, Galimand M, Tuambilangana F, Courvalin P, Cattoir V. 2014. Overexpression of the novel MATE fluoroquinolone efflux pump FepA in Listeria monocytogenes is driven by inactivation of its local repressor FepR. PLoS ONE 9: e106340.

Guillard T, Cambau E, Neuwirth C, Nenninger T, Mbadi A, Brasme L, Vernet-Garnier V, Bajolet O, de Champs C. 2012. Description of a 2,683-base-pair plasmid containing $q n r D$ in two Providencia rettgeri isolates. Antimicrob Agents Chemother 56: 565-568.

Guillard T, Grillon A, de Champs C, Cartier C, Madoux J, Bercot B, Lebreil AL, Lozniewski A, Riahi J, Vernet-Garnier V, et al. 2014. Mobile insertion cassette elements found in small non-transmissible plasmids in Proteeae may explain qnrD mobilization. PLoS ONE 9: e87801.

Habeeb MA, Haque A, Iversen A, Giske CG. 2014. Occurrence of virulence genes, $16 \mathrm{~S}$ rRNA methylases, and plasmid-mediated quinolone resistance genes in CTXM-producing Escherichia coli from Pakistan. Eur J Clin Microbiol Infect Dis 33: 399-409.

Hansen LH, Jensen LB, Sorensen HI, Sorensen SJ. 2007. Substrate specificity of the OqxAB multidrug resistance pump in Escherichia coli and selected enteric bacteria. J Antimicrob Chemother 60: 145-147.

Hata M, Suzuki M, Matsumoto M, Takahashi M, Sato K, Ibe S, Sakae K. 2005. Cloning of a novel gene for quinolone resistance from a transferable plasmid in Shigella flexneri 2b. Antimicrob Agents Chemother 49: 801-803.

Hay T, Fraud S, Lau CH, Gilmour C, Poole K. 2013. Antibiotic inducibility of the mexXY multidrug efflux operon of Pseudomonas aeruginosa: Involvement of the MexZ anti-repressor ArmZ. PLoS ONE 8: e56858.

Hearnshaw SJ, Edwards MJ, Stevenson CE, Lawson DM, Maxwell A. 2014. A new crystal structure of the bifunctional antibiotic simocyclinone D8 bound to DNA gyrase gives fresh insight into the mechanism of inhibition. J Mol Biol 426: 2023-2033.

Heeb S, Fletcher MP, Chhabra SR, Diggle SP, Williams P, Camara M. 2011. Quinolones: From antibiotics to autoinducers. FEMS Microbiol Rev 35: 247-274.

Hegde SS, Vetting MW, Roderick SL, Mitchenall LA, Maxwell A, Takiff HE, Blanchard JS. 2005. A fluoroquinolone resistance protein from Mycobacterium tuberculosis that mimics DNA. Science 308: 1480-1483.

Hegde SS, Vetting MW, Mitchenall LA, Maxwell A, Blanchard JS. 2011. Structural and biochemical analysis of the pentapeptide repeat protein $E f_{s} \mathrm{Qnr}$, a potent DNA gyrase inhibitor. Antimicrob Agents Chemother 55: 110-117.

Hiasa H. 2002. The Glu-84 of the ParC subunit plays critical roles in both topoisomerase IV-quinolone and topoisomerase IV-DNA interactions. Biochemistry 41: 1177911785.

Hiasa H, Yousef DO, Marians KJ. 1996. DNA strand cleavage is required for replication fork arrest by a frozen topoisomerase-quinolone-DNA ternary complex. J Biol Chem 271: 26424-26429. 
Ho PL, Ng KY, Lo WU, Law PY, Lai EL, Wang Y, Chow KH. 2016. Plasmid-mediated OqxAB is an important mechanism for nitrofurantoin resistance in Escherichia coli. Antimicrob Agents Chemother 60: 537-543.

Hooper DC. 1997. Bacterial topoisomerases, anti-topoisomerases, and anti-topoisomerase resistance. Clin Infect Dis 27: S54-S63.

Hooper DC. 2003. Mechanisms of quinolone resistance. In Quinolone antimicrobial agents, 3rd ed. (ed. Hooper DC, Rubinstein E), pp. 41-67. ASM, Washington, DC.

Howard BM, Pinney RJ, Smith JT. 1993. 4-Quinolone bactericidal mechanisms. Arzneimittel-Forschung 43: 1125 1129.

Huang J, O'Toole PW, Shen W, Amrine-Madsen H, Jiang X, Lobo N, Palmer LM, Voelker L, Fan F, Gwynn MN, et al 2004. Novel chromosomally encoded multidrug efflux transporter MdeA in Staphylococcus aureus. Antimicrob Agents Chemother 48: 909-917.

Huband MD, Cohen MA, Zurack M, Hanna DL, Skerlos LA, Sulavik MC, Gibson GW, Gage JW, Ellsworth E, Stier MA et al. 2007. In vitro and in vivo activities of PD 0305970 and PD 0326448, new bacterial gyrase/topoisomerase inhibitors with potent antibacterial activities versus multidrug-resistant gram-positive and fastidious organism groups. Antimicrob Agents Chemother 51: 1191-1201.

Ingavale $\mathrm{S}$, Van Wamel W, Luong TT, Lee CY, Cheung AL. 2005. Rat/MgrA, a regulator of autolysis, is a regulator of virulence genes in Staphylococcus aureus. Infect Immun 73: $1423-1431$.

Ito $\mathrm{H}$, Yoshida $\mathrm{H}$, Bogaki-Shonai $\mathrm{M}$, Niga T, Hattori $\mathrm{H}$, Nakamura S. 1994. Quinolone resistance mutations in the DNA gyrase gyrA and gyrB genes of Staphylococcus aureus. Antimicrob Agents Chemother 38: 2014-2023.

Jacoby GA, Hooper DC. 2013. Phylogenetic analysis of chromosomally determined Qnr and related proteins. Antimicrob Agents Chemother 57: 1930-1934.

Jacoby GA, Walsh KE, Mills DM, Walker VJ, Oh H, Robicsek A, Hooper DC. 2006. qnrB, another plasmid-mediated gene for quinolone resistance. Antimicrob Agents Chemother 50: 1178-1182.

Jacoby G, Cattoir V, Hooper D, Martínez-Martínez L, Nordmann P, Pascual A, Poirel L, Wang M. 2008. qnr gene nomenclature. Antimicrob Agents Chemother 52: $2297-$ 2299.

Jacoby GA, Gacharna N, Black TA, Miller GH, Hooper DC. 2009. Temporal appearance of plasmid-mediated quinolone resistance genes. Antimicrob Agents Chemother 53: 1665-1666.

Jacoby GA, Griffin CM, Hooper DC. 2011. Citrobacter spp. as a source of $q n r B$ alleles. Antimicrob Agents Chemother 55: 4979-4984.

Jacoby GA, Corcoran MA, Mills DM, Griffin CM, Hooper DC. 2013. Mutational analysis of quinolone resistance protein QnrB1. Antimicrob Agents Chemother 57: 5733-5736.

Jacoby GA, Strahilevitz J, Hooper DC. 2014. Plasmid-mediated quinolone resistance. Microbiol Spectr doi: 10. 1128/microbiolspec.PLAS-0006-2013.

Jacoby GA, Corcoran MA, Hooper DC. 2015. The protective effect of Qnr on agents other than quinolones that target
DNA gyrase. Antimicrob Agent Chemother 59: 66896695.

Jair KW, Yu X, Skarstad K, Thöny B, Fujita N, Ishihama A, Wolf RE Jr, 1996. Transcriptional activation of promoters of the superoxide and multiple antibiotic resistance regulons by Rob, a binding protein of the Escherichia coli origin of chromosomal replication. J Bacteriol 178: 2507-2513.

Jakobsen L, Cattoir V, Jensen KS, Hammerum AM, Nordmann P, Frimodt-Moller N. 2012. Impact of low-level fluoroquinolone resistance genes qnrA1, qnrB19 and qnrS1 on ciprofloxacin treatment of isogenic Escherichia coli strains in a murine urinary tract infection model. J Antimicrob Chemother 67: 2438-2444.

Kaatz GW, DeMarco CE, Seo SM. 2006. MepR, a repressor of the Staphylococcus aureus MATE family multidrug efflux pump MepA, is a substrate-responsive regulatory protein. Antimicrob Agents Chemother 50: 1276-1281.

Kern G, Basarab GS, Andrews B, Schuck V, Stone G, Kutschke A, Beaudoin M-E, San Martin M, Brassil P, Fan JH, et al. 2011. A DNA gyrase inhibitor with a novel mode of inhibition and in vivo efficacy. 51st Interscience Conference on Antimicrobial Agents and Chemotherapy (ICAAC), Abstract F1-1840. Chicago, September 17-20.

Khodursky AB, Cozzarelli NR. 1998. The mechanism of inhibition of topoisomerase IV by quinolone antibacterials. J Biol Chem 273: 27668-27677.

Khodursky AB, Zechiedrich EL, Cozzarelli NR. 1995. Topoisomerase IV is a target of quinolones in Escherichia coli. Proc Natl Acad Sci 92: 11801-11805.

Kim ES, Hooper DC. 2014. Clinical importance and epidemiology of quinolone resistance. Infect Chemother 46: 226-238.

Kim HB, Park CH, Kim CJ, Kim EC, Jacoby GA, Hooper DC. 2009a. Prevalence of plasmid-mediated quinolone resistance determinants over a 9-year period. Antimicrob Agents Chemother 53: 639-645.

Kim HB, Wang M, Park CH, Kim EC, Jacoby GA, Hooper DC. 2009b. oq $\times A B$ encoding a multidrug efflux pump in human clinical isolates of Enterobacteriaceae. Antimicrob Agents Chemother 53: 3582-3584.

Kim ES, Chen C, Braun M, Kim HY, Okumura R, Wang Y, Jacoby GA, Hooper DC. 2015. Interactions between QnrB, QnrB mutants, and DNA gyrase. Antimicrob Agents Chemother 59: 5413-5419.

Klyachko KA, Schuldiner S, Neyfakh AA. 1997. Mutations affecting substrate specificity of the Bacillus subtilis multidrug transporter Bmr. J Bacteriol 179: 2189-2193.

Köhler T, Michea-Hamzehpour M, Henze U, Gotoh N, Curty L, Pechère JC. 1997a. Characterization of MexEMexF-OprN, a positively regulated multidrug efflux system of Pseudomonas aeruginosa. Mol Microbiol 23: 345354.

Köhler T, Michea-Hamzehpour M, Plesiat P, Kahr AL, Pechère JC. 1997b. Differential selection of multidrug efflux systems by quinolones in Pseudomonas aeruginosa. Antimicrob Agents Chemother 41: 2540-2543.

Kreuzer KN, Cozzarelli NR. 1979. Escherichia coli mutants thermosensitive for deoxyribonucleic acid gyrase subunit A: Effects on deoxyribonucleic acid replication, transcription, and bacteriophage growth. J Bacteriol 140: $424-435$. 
D.C. Hooper and G.A. Jacoby

Kumar R, Shankar MB, Nagaraja V. 2014. Molecular basis for the differential quinolone susceptibility of mycobacterial DNA gyrase. Antimicrob Agents Chemother.

Kumaraswami M, Schuman JT, Seo SM, Kaatz GW, Brennan RG. 2009. Structural and biochemical characterization of MepR, a multidrug binding transcription regulator of the Staphylococcus aureus multidrug efflux pump MepA. Nucleic Acids Res 37: 1211-1224.

Laponogov I, Sohi MK, Veselkov DA, Pan XS, Sawhney R, Thompson AW, McAuley KE, Fisher LM, Sanderson MR. 2009. Structural insight into the quinolone-DNA cleavage complex of type IIA topoisomerases. Nat Struct Mol Biol 16: 667-669.

Laponogov I, Veselkov DA, Crevel IM, Pan XS, Fisher LM, Sanderson MR. 2013. Structure of an "open" clamp type II topoisomerase-DNA complex provides a mechanism for DNA capture and transport. Nucleic Acids Res 41: 9911-9923.

Lesher GY, Forelich ED, Gruet MD, Bailey JH, Brundage RP 1962. 1,8-Naphthyridine derivatives. A new class of chemotherapeutic agents. J Med Pharm Chem 5: 1063-1068.

Lewin CS, Howard BM, Smith JT. 1991. Protein- and RNAsynthesis independent bactericidal activity of ciprofloxacin that involves the A subunit of DNA gyrase. J Med Microbiol 34: 19-22.

Li XZ, Nikaido H. 2004. Efflux-mediated drug resistance in bacteria. Drugs 64: 159-204.

Li XZ, Nikaido H. 2009. Efflux-mediated drug resistance in bacteria: An update. Drugs 69: 1555-1623.

Li XZ, Barré N, Poole K. 2000a. Influence of the MexAMexB-OprM multidrug efflux system on expression of the MexC-MexD-OprJ and MexE-MexF-OprN multidrug efflux systems in Pseudomonas aeruginosa. J Antimicrob Chemother 46: 885-893.

Li XZ, Zhang L, Poole K. 2000b. Interplay between the MexA-MexB-OprM multidrug efflux system and the outer membrane barrier in the multiple antibiotic resistance of Pseudomonas aeruginosa. J Antimicrob Chemother 45: 433-436.

Li XZ, Plesiat P, Nikaido H. 2015. The challenge of effluxmediated antibiotic resistance in Gram-negative bacteria. Clin Microbiol Rev 28: 337-418.

Liao CH, Hsueh PR, Jacoby GA, Hooper DC. 2013. Risk factors and clinical characteristics of patients with $q n r-$ positive Klebsiella pneumoniae bacteraemia. J Antimicrob Chemother 68: 2907-2914.

Lin J, Michel LO, Zhang QJ. 2002. CmeABC functions as a multidrug efflux system in Campylobacter jejuni. Antimicrob Agents Chemother 46: 2124-2131.

Lomovskaya O, Lewis K, Matin A. 1995. EmrR is a negative regulator of the Escherichia coli multidrug resistance pump EmrAB. J Bacteriol 177: 2328-2334.

Lomovskaya O, Lee A, Hoshino K, Ishida H, Mistry A, Warren MS, Boyer E, Chamberland S, Lee VJ. 1999. Use of a genetic approach to evaluate the consequences of inhibition of efflux pumps in Pseudomonas aeruginosa. Antimicrob Agents Chemother 43: 1340-1346.

Luo N, Sahin O, Lin J, Michel LO, Zhang QJ. 2003. In vivo selection of Campylobacter isolates with high levels of fluoroquinolone resistance associated with gyrA muta- tions and the function of the CmeABC efflux pump Antimicrob Agents Chemother 47: 390-394.

Martínez-Martínez L, Pascual A, Jacoby GA. 1998. Quinolone resistance from a transferable plasmid. Lancet 351: 797-799.

Masuda N, Sakagawa E, Ohya S, Gotoh N, Tsujimoto H, Nishino T. 2000. Substrate specificities of MexABOprM, MexCD-OprJ, and MexXY-OprM efflux pumps in Pseudomonas aeruginosa. Antimicrob Agents Chemother 44: 3322-3327.

Matsuo Y, Eda S, Gotoh N, Yoshihara E, Nakae T. 2004. MexZ-mediated regulation of mexXY multidrug efflux pump expression in Pseudomonas aeruginosa by binding on the mexZ-mexX intergenic DNA. FEMS Microbiol Lett 238: $23-28$.

Maurice F, Broutin I, Podglajen I, Benas P, Collatz E, Dardel F. 2008. Enzyme structural plasticity and the emergence of broad-spectrum antibiotic resistance. EMBO Rep 9: 344-349.

Mégraud F. 1998. Epidemiology and mechanism of antibiotic resistance in Helicobacter pylori. Gastroenterology 115: $1278-1282$.

Miller PF, Gambino L, Sulavik MC, Gracheck SJ. 1994. Genetic relationship between soxRS and mar loci in promoting multiple antibiotic resistance in Escherichia coli. Antimicrob Agents Chemother 38: 1773-1779.

Miyamae S, Nikaido H, Tanaka Y, Yoshimura F. 1998. Active efflux of norfloxacin by Bacteroides fragilis. Antimicrob Agents Chemother 42: 2119-2121.

Miyamae S, Ueda O, Yoshimura F, Hwang J, Tanaka Y, Nikaido H. 2001. A MATE family multidrug efflux transporter pumps out fluoroquinolones in Bacteroides the taiotaomicron. Antimicrob Agents Chemother 45: 3341 3346.

Montero C, Mateu G, Rodriguez R, Takiff H. 2001. Intrinsic resistance of Mycobacterium smegmatis to fluoroquinolones may be influenced by new pentapeptide protein MfpA. Antimicrob Agents Chemother 45: 3387-3392.

Morais Cabral JH, Jackson AP, Smith CV, Shikotra N, Maxwell A, Liddington RC. 1997. Crystal structure of the breakage-reunion domain of DNA gyrase. Nature 388: 903-906.

Morita Y, Kataoka A, Shiota S, Mizushima T, Tsuchiya T. 2000. NorM of Vibrio parahaemolyticus is an $\mathrm{Na}^{+}$-driven multidrug efflux pump. J Bacteriol 182: 6694-6697.

Mustaev A, Malik M, Zhao X, Kurepina N, Luan G, Oppegard LM, Hiasa H, Marks KR, Kerns RJ, Berger JM, et al. 2014. Fluoroquinolone-gyrase-DNA complexes: Two modes of drug binding. J Biol Chem 289: 12300-12312.

Nakaminami H, Noguchi N, Sasatsu M. 2010. Fluoroquinolone efflux by the plasmid-mediated multidrug efflux pump QacB variant QacBIII in Staphylococcus aureus. Antimicrob Agents Chemother 54: 4107-4111.

Ng EY, Trucksis M, Hooper DC. 1996. Quinolone resistance mutations in topoisomerase IV: Relationship of the flqA locus and genetic evidence that topoisomerase IV is the primary target and DNA gyrase the secondary target of fluoroquinolones in Staphylococcus aureus. Antimicrob Agents Chemother 40: 1881-1888.

Nikaido H, Takatsuka Y. 2009. Mechanisms of RND multidrug efflux pumps. Biochim Biophys Acta 1794: 769-781. 
Nikaido H, Nikaido K, Harayama S. 1991. Identification and characterization of porins in Pseudomonas aeruginosa. J Biol Chem 266: 770-779.

Ogbolu DO, Daini OA, Ogunledun A, Alli AO, Webber MA. 2011. High levels of multidrug resistance in clinical isolates of Gram-negative pathogens from Nigeria. Int $J$ Antimicrob Agents 37: 62-66.

Ohki R, Murata M. 1997. bmr3, a third multidrug transporter gene of Bacillus subtilis. J Bacteriol 179: 1423-1427.

Oteo J, Cuevas O, López-Rodríguez I, Banderas-Florido A, Vindel A, Pérez-Vázquez M, Bautista V, Arroyo M, García-Caballero J, Marin-Casanova P, et al. 2009. Emergence of CTX-M-15-producing Klebsiella pneumoniae of multilocus sequence types $1,11,14,17,20,35$ and 36 as pathogens and colonizers in newborns and adults. J Antimicrob Chemother 64: 524-528.

Owens RC Jr, Ambrose PG. 2000. Clinical use of the fluoroquinolones. Med Clin N Am 84: 1447-1469.

Pan XS, Fisher LM. 1997. Targeting of DNA gyrase in Streptococcus pneumoniae by sparfloxacin: Selective targeting of gyrase or topoisomerase IV by quinolones. Antimicrob Agents Chemother 41: 471-474.

Pan XS, Fisher LM. 1998. DNA gyrase and topoisomerase IV are dual targets of clinafloxacin action in Streptococcus pneumoniae. Antimicrob Agents Chemother 42: 2810 2816.

Pan XS, Fisher LM. 1999. Streptococcus pneumoniae DNA gyrase and topoisomerase IV: Overexpression, purification, and differential inhibition by fluoroquinolones. Antimicrob Agents Chemother 43: 1129-1136.

Périchon B, Courvalin P, Galimand M. 2007. Transferable resistance to aminoglycosides by methylation of G1405 in $16 \mathrm{~S}$ rRNA and to hydrophilic fluoroquinolones by QepAmediated efflux in Escherichia coli. Antimicrob Agents Chemother 51: 2464-2469.

Picão RC, Poirel L, Demarta A, Silva CS, Corvaglia AR, Petrini O, Nordmann P. 2008. Plasmid-mediated quinolone resistance in Aeromonas allosaccharophila recovered from a Swiss lake. J Antimicrob Chemother 62: 948-950.

Piddock LJ, Walters RN, Diver JM. 1990. Correlation of quinolone MIC and inhibition of DNA, RNA, and protein synthesis and induction of the SOS response in Escherichia coli. Antimicrob Agents Chemother 34: 23312336.

Poelarends GJ, Mazurkiewicz P, Putman M, Cool RH, Veen HW, Konings WN. 2000. An ABC-type multidrug transporter of Lactococcus lactis possesses an exceptionally broad substrate specificity. Drug Resist Updat 3: 330-334.

Poirel L, Liard A, Rodriguez-Martinez JM, Nordmann P. 2005a. Vibrionaceae as a possible source of Qnr-like quinolone resistance determinants. J Antimicrob Chemother 56: 1118-1121.

Poirel L, Rodriguez-Martinez JM, Mammeri H, Liard A, Nordmann P. 2005b. Origin of plasmid-mediated quinolone resistance determinant QnrA. Antimicrob Agents Chemother 49: 3523-3525.

Poole K, Krebes K, McNally C, Neshat S. 1993. Multiple antibiotic resistance in Pseudomonas aeruginosa: Evidence for involvement of an efflux operon. $J$ Bacteriol 175: $7363-7372$
Poole K, Gotoh N, Tsujimoto H, Zhao QX, Wada A, Yamasaki T, Neshat S, Yamagishi JI, Li XZ, Nishino T. 1996a. Overexpression of the mexC-mexD-oprJ efflux operon in $n f x B$ - type multidrug-resistant strains of Pseudomonas aeruginosa. Mol Microbiol 21: 713-724.

Poole K, Tetro K, Zhao QX, Neshat S, Heinrichs DE, Bianco N. 1996b. Expression of the multidrug resistance operon mexA-mexB-oprM in Pseudomonas aeruginosa: mexR encodes a regulator of operon expression. Antimicrob Agents Chemother 40: 2021-2028.

Pradel E, Pagès JM. 2002. The AcrAB-TolC efflux pump contributes to multidrug resistance in the nosocomial pathogen Enterobacter aerogenes. Antimicrob Agents Chemother 46: 2640-2643.

Putman M, Van Veen HW, Konings WN. 2000. Molecular properties of bacterial multidrug transporters. Microbiol Mol Biol Rev 64: 672-693.

Quiroga MP, Orman B, Errecalde L, Kaufman S, Centron D. 2015. Characterization of Tn6238 with a new allele of aac $\left(6^{\prime}\right)$-Ib-cr. Antimicrob Agents Chemother 59: $2893-$ 2897.

Ribeiro TG, Novais A, Branquinho R, Machado E, Peixe L. 2015. Phylogeny and comparative genomics unveil independent diversification trajectories of $q n r B$ and genetic platforms within particular Citrobacter species. Antimicrob Agents Chemother 59: 5951-5958.

Robicsek A, Strahilevitz J, Jacoby GA, Macielag M, Abbanat D, Park CH, Bush K, Hooper DC. 2006. Fluoroquinolone-modifying enzyme: A new adaptation of a common aminoglycoside acetyltransferase. Nat Med 12: 83-88.

Rodríguez-Martínez JM, Velasco C, García I, Cano ME, Martínez-Martínez L, Pascual A. 2007. Mutant prevention concentrations of fluoroquinolones for Enterobacteriaceae expressing the plasmid-carried quinolone resistance determinant qnrA1. Antimicrob Agents Chemother 51: 2236-2239.

Rodríguez-Martínez JM, Pichardo C, García I, Pachón-Ibañez ME, Docobo-Pérez F, Pascual A, Pachón J, MartínezMartínez L. 2008a. Activity of ciprofloxacin and levofloxacin in experimental pneumonia caused by Klebsiella pneumoniae deficient in porins, expressing active efflux and producing QnrA1. Clin Microbiol Infect 14: 691-697.

Rodríguez-Martínez JM, Velasco C, Briales A, García I, Conejo MC, Pascual A. 2008b. Qnr-like pentapeptide repeat proteins in Gram-positive bacteria. J Antimicrob Chemother 61: 1240-1243.

Rodríguez-Martínez JM, Díaz de Alba P, Briales A, Machuca J, Lossa M, Fernández-Cuenca F, Rodríguez Baño J, Martínez-Martínez L, Pascual A. 2013. Contribution of OqxAB efflux pumps to quinolone resistance in extended-spectrum- $\beta$-lactamase-producing Klebsiella pneumoniae. J Antimicrob Chemother 68: 68-73.

Rosenberg EY, Bertenthal D, Nilles ML, Bertrand KP, Nikaido H. 2003. Bile salts and fatty acids induce the expression of Escherichia coli AcrAB multidrug efflux pump through their interaction with Rob regulatory protein. Mol Microbiol 48: 1609-1619.

Sabtcheva S, Kaku M, Saga T, Ishii Y, Kantardjiev T. 2009. High prevalence of the $a a c\left(6^{\prime}\right)-I b$-cr gene and its dissemination among Enterobacteriaceae isolates by CTX-M-15 plasmids in Bulgaria. Antimicrob Agents Chemother 53: $335-336$. 
D.C. Hooper and G.A. Jacoby

Saga T, Sabtcheva S, Mitsutake K, Ishii Y, Tateda K, Yamaguchi K, Kaku M. 2013. Characterization of qnrB-like genes in Citrobacter species of the American type culture collection. Antimicrob Agents Chemother 57: 2863-2866.

Sánchez MB, Hernández A, Rodríguez-Martínez JM, Martínez-Martínez L, Martínez JL. 2008. Predictive analysis of transmissible quinolone resistance indicates Stenotrophomonas maltophilia as a potential source of a novel family of Qnr determinants. BMC Microbiol 8: 148-161.

Schindler BD, Patel D, Seo SM, Kaatz GW. 2013. Mutagenesis and modeling to predict structural and functional characteristics of the Staphylococcus aureus MepA multidrug efflux pump. J Bacteriol 195: 523-533.

Schindler BD, Frempong-Manso E, DeMarco CE, Kosmidis C, Matta V, Seo SM, Kaatz GW. 2015. Analyses of multidrug efflux pump-like proteins encoded on the Staphylococcus aureus chromosome. Antimicrob Agents Chemother 59: 747-748.

Schmitz FJ, Jones ME, Hofmann B, Hansen B, Scheuring S, Lückefahr MFA, Verhoef J, Hadding U, Heinz HP, Köhrer K. 1998. Characterization of $\operatorname{grl}$, grlB, gyrA, and $\operatorname{gyr} B$ mutations in 116 unrelated isolates of Staphylococcus au reus and effects of mutations on ciprofloxacin MIC. Antimicrob Agents Chemother 42: 1249-1252.

Shen LL, Kohlbrenner WE, Weigl D, Baranowski J. 1989. Mechanism of quinolone inhibition of DNA gyrase. Appearance of unique norfloxacin binding sites in enzymeDNA complexes. J Biol Chem 264: 2973-2978.

Sorensen AH, Hansen LH, Johannesen E, Sorensen SJ. 2003. Conjugative plasmid conferring resistance to olaquindox. Antimicrob Agents Chemother 47: 798-799.

Strahilevitz J, Hooper DC. 2005. Dual targeting of topoisomerase IV and gyrase to reduce mutant selection: $\mathrm{Di}$ rect testing of the paradigm by using WCK-1734, a new fluoroquinolone, and ciprofloxacin. Antimicrob Agents Chemother 49: 1949-1956.

Tavio MM, Jacoby GA, Hooper DC. 2014. QnrS1 structureactivity relationships. J Antimicrob Chemother 69: 2102 2109.

Tran JH, Jacoby GA. 2002. Mechanism of plasmid-mediated quinolone resistance. Proc Natl Acad Sci 99: 5638-5642.

Tran JH, Jacoby GA, Hooper DC. 2005. Interaction of the plasmid-encoded quinolone resistance protein Qnr with Escherichia coli DNA gyrase. Antimicrob Agents Chemother 49: 118-125.

Trucksis M, Wolfson JS, Hooper DC. 1991. A novel locus conferring fluoroquinolone resistance in Staphylococcus aureus. J Bacteriol 173: 5854-5860.

Truong-Bolduc QC, Hooper DC. 2007. Transcriptional regulators NorG and MgrA modulate resistance to both quinolones and $\beta$-lactams in Staphylococcus aureus. Bacteriol 189: 2996-3005.

Truong-Bolduc QC, Hooper DC. 2010. Phosphorylation of MgrA and its effect on expression of the NorA and NorB efflux pumps of Staphylococcus aureus. J Bacteriol 192: $2525-2534$.

Truong-Bolduc QC, Dunman PM, Strahilevitz J, Projan SJ, Hooper DC. 2005. MgrA is a multiple regulator of two new efflux pumps in Staphylococcus aureus. J Bacteriol 187: 2395-2405.
Truong-Bolduc QC, Strahilevitz J, Hooper DC. 2006. NorC, a new efflux pump regulated by MgrA of Staphylococcus aureus. Antimicrob Agents Chemother 50: 1104-1107.

Truong-Bolduc QC, Ding Y, Hooper DC. 2008. Posttranslational modification influences the effects of MgrA on norA expression in Staphylococcus aureus. J Bacteriol 190: $7375-7381$.

Truong-Bolduc QC, Bolduc GR, Okumura R, Celino B, Bevis J, Liao CH, Hooper DC. 2011a. Implication of the NorB efflux pump in the adaptation of Staphylococcus aureus to growth at acid $\mathrm{pH}$ and in resistance to moxifloxacin. Antimicrob Agents Chemother 55: 3214-3219.

Truong-Bolduc QC, Dunman PM, Eidem T, Hooper DC. 2011b. Transcriptional profiling analysis of the global regulator NorG, a GntR-like protein of Staphylococcus aureus. J Bacteriol 193: 6207-6214.

Truong-Bolduc QC, Liao C-H, Villet R, Bolduc GR, Estabrooks Z, Taguezem GF, Hooper DC. 2012. Reduced aeration affects the expression of the NorB efflux pump of Staphylococcus aureus by posttranslational modification of MgrA. J Bacteriol 194: 1823-1834.

Tsukamura M, Nakamura E, Yoshii S, Amano H. 1985. Therapeutic effect of a new antibacterial substance ofloxacin (DL8280) on pulmonary tuberculosis. Am Rev Resp Dis 131: 352-356.

Ubukata K, Itoh-Yamashita N, Konno M. 1989. Cloning and expression of the norA gene for fluoroquinolone resistance in Staphylococcus aureus. Antimicrob Agents Chemother 33: 1535-1539.

Vetting MW, Park CH, Hegde SS, Jacoby GA, Hooper DC, Blanchard JS. 2008. Mechanistic and structural analysis of aminoglycoside $N$-acetyltransferase $\mathrm{AAC}\left(6^{\prime}\right)$-Ib and its bifunctional fluoroquinolone-active $\mathrm{AAC}\left(6^{\prime}\right)-\mathrm{Ib}-\mathrm{cr}$ variant. Biochemistry 47: 9825-9835.

Vetting MW, Hegde SS, Wang M, Jacoby GA, Hooper DC, Blanchard JS. 2011. Structure of QnrB1, a plasmid-mediated fluoroquinolone resistance factor. J Biol Chem 286: 25265-25273.

Vinué L, Corcoran MA, Hooper DC, Jacoby GA. 2015. Mutations that enhance the ciprofloxacin resistance of $E s$ cherichia coli with qnrA1. Antimicrob Agents Chemother 60: 1537-1545.

Wang JC. 1996. DNA topoisomerases. Annu Rev Biochem 65: 635-692.

Wang M, Guo Q, Xu X, Wang X, Ye X, Wu S, Hooper DC, Wang M. 2009. New plasmid-mediated quinolone resistance gene, $q n r C$, found in a clinical isolate of Proteus mirabilis. Antimicrob Agents Chemother 53: 1892-1897.

Weigel LM, Anderson GJ, Facklam RR, Tenover FC. 2001. Genetic analyses of mutations contributing to fluoroquinolone resistance in clinical isolates of Streptococcus pneumoniae. Antimicrob Agents Chemother 45: 35173523.

Wentzell LM, Maxwell A. 2000. The complex of DNA gyrase and quinolone drugs on DNA forms a barrier to the T7 DNA polymerase replication complex. J Mol Biol 304: 779-791.

Westfall LW, Carty NL, Layland N, Kuan P, Colmer-Hamood JA, Hamood AN. 2006. mvaT mutation modifies the expression of the Pseudomonas aeruginosa multidrug efflux operon mexEF-oprN. FEMS Microbiol Lett 255: 247-254. 
Willmott CJ, Maxwell A. 1993. A single point mutation in the DNA gyrase A protein greatly reduces binding of fluoroquinolones to the gyrase-DNA complex. Antimicrob Agents Chemother 37: 126-127.

Willmott CJ, Critchlow SE, Eperon IC, Maxwell A. 1994. The complex of DNA gyrase and quinolone drugs with DNA forms a barrier to transcription by RNA polymerase. J Mol Biol 242: 351-363.

Wohlkonig A, Chan PF, Fosberry AP, Homes P, Huang J, Kranz M, Leydon VR, Miles TJ, Pearson ND, Perera RL, et al. 2010. Structural basis of quinolone inhibition of type IIA topoisomerases and target-mediated resistance. Nat Struct Mol Biol 17: 1152-1153.

Wong MH, Chan EW, Chen S. 2015. Evolution and dissemination of OqxAB-like efflux pumps, an emerging quinolone resistance determinant among members of Enterobacteriaceae. Antimicrob Agents Chemother 59: 3290-3297.

Xiong X, Bromley EH, Oelschlaeger P, Woolfson DN, Spencer J. 2011. Structural insights into quinolone antibiotic resistance mediated by pentapeptide repeat proteins: Conserved surface loops direct the activity of a Qnr protein from a Gram-negative bacterium. Nucleic Acids Res 39: 3917-3927.

Yamada Y, Hideka K, Shiota S, Kuroda T, Tsuchiya T. 2006. Gene cloning and characterization of SdrM, a chromosomally encoded multidrug efflux pump, from Staphylococcus aureus. Biol Pharm Bull 29: 554-556.

Yamane K, Wachino J, Suzuki S, Kimura K, Shibata N, Kato H, Shibayama K, Konda T, Arakawa Y. 2007. New plasmid-mediated fluoroquinolone efflux pump, QepA, found in an Escherichia coli clinical isolate. Antimicrob Agents Chemother 51: 3354-3360.

Yang S, Clayton SR, Zechiedrich EL. 2003. Relative contributions of the AcrAB, MdfA and NorE efflux pumps to quinolone resistance in Escherichia coli. J Antimicrob Chemother 51: 545-556.

Yoon EJ, Courvalin P, Grillot-Courvalin C. 2013. RND-type efflux pumps in multidrug-resistant clinical isolates of Acinetobacter baumannii: Major role for AdeABC overexpression and AdeRS mutations. Antimicrob Agents Chemother 57: 2989-2995.

Yoon EJ, Chabane YN, Goussard S, Snesrud E, Courvalin P, De E, Grillot-Courvalin C. 2015. Contribution of resistance-nodulation-cell division efflux systems to antibiot- ic resistance and biofilm formation in Acinetobacter baumannii. MBio 6: e00309-e00315.

Yoshida H, Bogaki M, Nakamura M, Nakamura S. 1990. Quinolone resistance-determining region in the DNA gyrase gyrA gene of Escherichia coli. Antimicrob Agents Chemother 34: 1271-1272.

Yoshida H, Bogaki M, Nakamura M, Yamanaka LM, Nakamura S. 1991. Quinolone resistance-determining region in the DNA gyrase gyrB gene of Escherichia coli. Antimicrob Agents Chemother 35: 1647-1650.

Yoshida H, Nakamura M, Bogaki M, Ito H, Kojima T, Hattori H, Nakamura S. 1993. Mechanism of action of quinolones against Escherichia coli DNA gyrase. Antimicrob Agents Chemother 37: 839-845.

Yu JL, Grinius L, Hooper DC. 2002. NorA functions as a multidrug efflux protein in both cytoplasmic membrane vesicles and reconstituted proteoliposomes. J Bacteriol 184: $1370-1377$.

Yu EW, Aires JR, Nikaido H. 2003. AcrB multidrug efflux pump of Escherichia coli: Composite substrate-binding cavity of exceptional flexibility generates its extremely wide substrate specificity. J Bacteriol 185: 5657-5664.

Yu EW, Aires JR, McDermott G, Nikaido H. 2005. A periplasmic drug-binding site of the AcrB multidrug efflux pump: A crystallographic and site-directed mutagenesis study. J Bacteriol 187: 6804-6815.

Zhang L, Li XZ, Poole K. 2001. SmeDEF multidrug efflux pump contributes to intrinsic multidrug resistance in Stenotrophomonas maltophilia. Antimicrob Agents Chemother 45: 3497-3503.

Zhang S, Sun J, Liao XP, Hu QJ, Liu BT, Fang LX, Deng H, Ma J, Xiao X, Zhu HQ, et al. 2013. Prevalence and plasmid characterization of the qnrD determinant in Enterobacteriaceae isolated from animals, retail meat products, and humans. Microb Drug Resist 19: 331-335.

Zhao J, Chen Z, Chen S, Deng Y, Liu Y, Tian W, Huang X, Wu C, Sun Y, Zeng Z, et al. 2010. Prevalence and dissemination of oqxAB in Escherichia coli Isolates from animals, farmworkers, and the environment. Antimicrob Agents Chemother 54: 4219-4224.

Zhao L, Zhang J, Zheng B, Wei Z, Shen P, Li S, Li L, Xiao Y. 2015. Molecular epidemiology and genetic diversity of fluoroquinolone-resistant Escherichia coli isolates from patients with community-onset infections in 30 Chinese county hospitals. J Clin Microbiol 53: 766-770. 


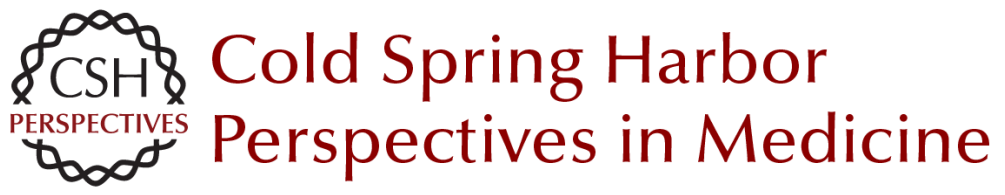

\title{
Topoisomerase Inhibitors: Fluoroquinolone Mechanisms of Action and Resistance
}

\author{
David C. Hooper and George A. Jacoby
}

Cold Spring Harb Perspect Med 2016; doi: 10.1101/cshperspect.a025320 originally published online July 22,2016

\section{Subject Collection Antibiotics and Antibiotic Resistance}

Fosfomycin: Mechanism and Resistance Lynn L. Silver

Pleuromutilins: Potent Drugs for Resistant Bugs

--Mode of Action and Resistance

Susanne Paukner and Rosemarie Riedl

Appropriate Targets for Antibacterial Drugs Lynn L. Silver

Lincosamides, Streptogramins, Phenicols, and Pleuromutilins: Mode of Action and Mechanisms of Resistance

Stefan Schwarz, Jianzhong Shen, Kristina Kadlec, et al.

Resistance to Macrolide Antibiotics in Public Health Pathogens

Corey Fyfe, Trudy H. Grossman, Kathy Kerstein, et al.

Bacterial Protein Synthesis as a Target for Antibiotic Inhibition Stefan Arenz and Daniel N. Wilson

Antibacterial Antifolates: From Development through Resistance to the Next Generation Alexavier Estrada, Dennis L. Wright and Amy C. Anderson

Antibacterial Drug Discovery Targeting the Lipopolysaccharide Biosynthetic Enzyme LpxC Alice L. Erwin
The Whys and Wherefores of Antibiotic

Resistance

Cameron R. Strachan and Julian Davies

$\beta$-Lactamases: A Focus on Current Challenges

Robert A. Bonomo

Approved Glycopeptide Antibacterial Drugs:

Mechanism of Action and Resistance

Daina Zeng, Dmitri Debabov, Theresa L. Hartsell, et al.

Mechanism of Action and Resistance to

Daptomycin in Staphylococcus aureus and

Enterococci

William R. Miller, Arnold S. Bayer and Cesar A.

Arias

Polymyxin: Alternative Mechanisms of Action and

Resistance

Michael J. Trimble, Patrik Mlynárcik, Milan Kolár, et al.

Topoisomerase Inhibitors: Fluoroquinolone

Mechanisms of Action and Resistance

David C. Hooper and George A. Jacoby

$\beta$-Lactams and $\beta$-Lactamase Inhibitors: An

Overview

Karen Bush and Patricia A. Bradford

Rifamycins, Alone and in Combination David M. Rothstein

For additional articles in this collection, see http://perspectivesinmedicine.cshlp.org/cgi/collection/ 